\title{
Modelling sediment assimilative capacity and organic carbon degradation efficiency at marine fish farms
}

\author{
Francisco Bravo*, Jonathan Grant \\ Dalhousie University, Department of Oceanography, 1355 Oxford Street, Halifax, Nova Scotia B3H 4J1, Canada
}

\begin{abstract}
The eutrophication of sediments underlying marine fish farms is one of the major environmental concerns of the industry and regulatory agencies. In this study, a mechanistic model of sediment geochemistry was developed to: (1) determine maximum organic loads that can be degraded without leading to eutrophicated conditions, (2) predict the transition to suboxic conditions as a result of organic enrichment, and (3) predict sulfide levels in surface sediments, a key regulatory variable in Canada. A new definition is proposed for sediment assimilative capacity (AC) of marine fish farms, as the gross deposition rate of organic wastes that maximizes total organic carbon $\left(\mathrm{C}_{\text {org }}\right)$ degradation rates while preventing sediment sulfide accumulations in surface sediments (upper $2 \mathrm{~cm}$ ) above regulatory limits $\left(\mathrm{AC}-\mathrm{H}_{2} \mathrm{~S}\right)$. Model results were consistent with empirical observations and highlight the influence that organic loading history, hydrodynamics, and microbial activity have on assimilative capacity. $\mathrm{AC}-\mathrm{H}_{2} \mathrm{~S}$ varied between 0.6 to $22.1 \mathrm{~g} \mathrm{C}_{\text {org }} \mathrm{m}^{-2}$ $\mathrm{d}^{-1}$ in poorly flushed environments, with no upper limit defined in environments exposed to mean tidal currents $>9.5 \mathrm{~cm} \mathrm{~s}^{-1}$ (dispersion scenarios), where most fish farm organic wastes are dispersed to the far-field or resuspended after deposition below fish cages. The combination of diagenetic modelling and geochemical indicators may contribute significantly to the development of more effective tools for site selection and environmental management of marine fish farms. At this stage, the model should be considered as a proof of concept, developed with the purpose of verifying the utility of assimilative capacity for real-world application. Further validation is still required.
\end{abstract}

KEY WORDS: Assimilative capacity $\cdot$ Degradation efficiency $\cdot$ Salmon aquaculture $\cdot$ Organic enrichment $\cdot$ Sulfide $\cdot$ Sediment

\section{INTRODUCTION}

Ensuring sustainable aquaculture production in coastal areas requires careful attention to environmental interactions with the benthos and water column. Among near-field interactions, the eutrophication of sediments underlying fish farm cages due to deposition of organic-rich solid wastes (feces, uneaten feed) represents a major factor influencing productive capacity and social licence to operate. The generation and release of organic wastes to the environment mostly depend on the farm size and husbandry practices (e.g. feed conversion rates, feeding strategies, fish biomass, etc.). Their dispersion in the

*Corresponding author: bravofco@gmail.com water column and deposition to sediments depends on physical conditions, including hydrodynamics and water depth. Once at the bed, wastes can accumulate or be degraded, buried or resuspended in the water column. Degradation of organic wastes (by oxic and anoxic respiration) is a function of the supply of oxidants to surface sediments and the composition and successional stage of benthic communities carrying out degradation. These factors also define the recovery rate of fallowed sites and the return of geochemical and biological indicators to the bounds of natural variation.

The consequences of excessive organic loading are sediment hypoxia and prominence of anaerobic pro-

(C) The authors 2018. Open Access under Creative Commons by Attribution Licence. Use, distribution and reproduction are unrestricted. Authors and original publication must be credited. 
cesses, notably sulfate reduction and release of sulfides toxic to infauna. Visual signs of this transition include the appearance of sulfur-oxidizing bacterial mats, shallowing of the redox potential discontinuity layer (RPD) (Mulsow et al. 2006), and progressive loss of macrobenthic and meiofaunal communities due to reducing conditions (Pearson \& Rosenberg 1978, Mazzola et al. 2000, Meyer-Reil \& Köster 2000, Nilsson \& Rosenberg 2000, Buschmann et al. 2006, Wilding et al. 2012).

A cost-effective indicator used to monitor and research benthic impacts of salmon farming is the total sulfide $\left(\mathrm{S}^{2-}\right)$ concentration (Wildish et al. 2001, Hargrave et al. 2008), which increases with organic loading as demonstrated by Brooks (2001), Brooks \& Mahnken (2003), Holmer et al. (2005), Hargrave et al. (2008), and Hargrave (2010). Its application in monitoring programs currently includes Maine (USA), Canada, Australia, and others. Unfortunately, this measure belies the complexity of sulfur dynamics in sediments and its interactions with organic wastes and other elemental cycles, notably iron. In ambient conditions (no farm), $\mathrm{O}_{2}$ availability alternates between periods of surplus and deficit in relation with major consumptive processes (oxic respiration and oxidation of reduced substances), a dynamic that can be observed naturally at daily to seasonal scales. Sulfide produced by sulfate reduction can be reoxidized in the presence of $\mathrm{O}_{2}$ or precipitated to elemental sulfur $\left(\mathrm{S}^{0}\right)$ and sulfide minerals (mostly $\mathrm{FeS}$ and $\mathrm{FeS}_{2}$ ). Precipitation of sulfide minerals is an important mechanism that prevents sulfide diffusion and re-oxidation into the oxic zone of sediments, which mostly occurs under $\mathrm{O}_{2}$ deficiency and low concentrations of metal oxides. The restoration of oxic conditions may occur by increased renewal and oxygenation of bottom waters, decreased organic carbon $\left(\mathrm{C}_{\text {org }}\right)$ loading, or reworking of surface sediments. The accumulation of precipitated sulfur and other reduced compounds $\left(\mathrm{NH}_{3}\right.$, $\mathrm{Fe}^{2+}$, and $\mathrm{Mn}^{2+}$ ) occurs naturally (Fossing et al. 2004), but it may strongly intensify in fish farm sediments.

Given the complexity of sediment biogeochemical interactions, and the wide range of coastal environments in which fish farms are located, the transition to anoxic conditions occurs neither at fixed wastage rates (i.e. fish cage output of organic wastes) nor at fixed deposition rates to sediments. The ability of sediments to digest organic input and remain oxic is referred to as assimilative capacity, and is an important criterion for maintaining ecosystem sedimentary services (Omori et al. 1994). However, 'remain oxic' is a qualitative term that must be calibrated in terms of both oxygen and sulfide thresholds. Despite its impor- tance, site-specific considerations of benthic assimilative capacity of organic wastes and dependencies on the local history of $\mathrm{C}_{\text {org }}$ degradation (Zirino et al. 2013) are barely considered in managing and selection of fish farm sites. Based on observations, $\mathrm{C}_{\text {org }}$ loading rates causing significant changes in benthic community structure and geochemical parameters, particularly sulfide, vary by an order of magnitude from 0.36 to $11.4 \mathrm{~g} \mathrm{C}_{\text {org }} \mathrm{m}^{-2} \mathrm{~d}^{-1}$ (Cranston 1994, Hargrave 1994, Findlay \& Watling 1997, Gillibrand et al. 2002, Fisheries and Oceans Canada 2004, Chamberlain \& Stucchi 2007, Environment Canada 2009, Chang et al. 2012).

The relationship between organic deposition and benthic response is inherently a problem of sediment diagenesis. Previous models used to reproduce dynamics of fish farm sediments range from simplified depth-integrated models (Omori et al. 1994, Silvert \& Sowles 1996, Stigebrandt et al. 2004, De Gaetano et al. 2008) to more sophisticated approaches combining numerical models of fish growth at fish farms, particle dispersion and deposition, and benthic degradation (Brigolin et al. 2009, 2014). Omori et al. (1994) and Stigebrandt et al. (2004) have proposed steady-state models to predict threshold of organic loading to sediments. We build on this work and extend it to consider temporal dynamics, microbial activity, and bottom water renewal.

In the present study, a coupled mechanistic model simulating the production of organic wastes and their dispersion, deposition, resuspension, and degradation in sediments underlying salmon farms was developed to investigate aquaculture-sediment interactions and local assimilative capacity. After assessing the performance of model predictions with field observations, the model was specifically used to (1) investigate the evolution of total dissolved sulfide concentrations in organically enriched sediments and its value as an indicator of sediment quality, as well as (2) predict the capacity of sediments to degrade organic wastes while avoiding undesired benthic conditions in a broad range of hydrodynamic conditions. The sensitivity of state variables to model parameterization was analyzed to constrain the contribution of major early diagenetic processes.

\section{MATERIALS AND METHODS}

\section{Numerical model}

The numerical model is composed of 3 modules representing a marine salmon farm, the surrounding water column, and the benthos. Together, they simu- 
late the production of organic wastes at the fish farm and their fate once released to the environment (dispersion in the water column, deposition, degradation and accumulation in sediments). A detailed description of model equations and analytical forcing functions is provided in the Supplement (see Tables S1-S5 at www.int-res.com/articles/suppl/q010p309_supp. pdf). A schematic of the model is provided in Fig. S1 in the Supplement. The model was implemented in MATLAB (MATLAB R2013a, The MathWorks). Time stepping was conducted using the forward Euler method. Forcing conditions and diagenetic simulations were simultaneously computed. As result, a small time step (10 s) was required to solve sub-hour changes in net deposition and oxidant concentration (e.g. $\mathrm{O}_{2}$ ) in bottom water.

Fish farm operation and organic waste production

The production of organic wastes, including lost (uneaten) feed and feces, assumes a representative fish farm production cycle with the parameters listed in Table 1. Feeding practices of salmonids, including feeding frequency, ration size, and diet composition, vary considerably with body weight (measured on a scale) and length, and with growing conditions (culture density, temperature, and $\mathrm{O}_{2}$ renewal within cages) (Stead \& Laird 2002, Kaushik 2013). Feeding frequency of adult fish in net cages varies from 2 to 7 times per day, with twice per day being the most

Table 1. Parameters required for estimation of wastage rate (lost feed plus feces) for a single representative salmon farming cycle based on Stucchi et al. (2005), Petersen et al. (2005), and Chang et al. (2014). Digestion coefficient represents the proportion assimilated of ingested feed

\begin{tabular}{|c|c|}
\hline Parameter & Value \\
\hline Cage volume $\left(\mathrm{m}^{3}\right)$ & 6000 \\
\hline Cage depth (m) & 15 \\
\hline Cage-side length (m) & 20 \\
\hline Net pen bottom area $\left(\mathrm{m}^{2}\right)$ & 400 \\
\hline Weight of salmon smolts $\left(\mathrm{kg}\right.$ ind $\left.^{-1}\right)$ & 0.09 \\
\hline Harvest weight of salmon $\left(\mathrm{kg}\right.$ ind $\left.^{-1}\right)$ & 4.5 \\
\hline Culture density $\left(\mathrm{kg} \mathrm{m}^{-3}\right)$ & 8 \\
\hline Harvested biomass (kg) & 60000 \\
\hline Grow-out period (d) & 540 \\
\hline Lost feed/feed wastage (\%) & $0-8$ \\
\hline Percent mortality (individual-based) & 12 \\
\hline Digestive coefficient for salmon & 0.9 \\
\hline Organic C content in feed (dry weight; \%) & 52.3 \\
\hline Organic C content in feces (dry weight; \%) & 27.9 \\
\hline Settling velocity of feed pellets $\left(\mathrm{cm} \mathrm{s}^{-1}\right)$ & 10.9 \\
\hline Settling velocity of feces $\left(\mathrm{cm} \mathrm{s}^{-1}\right)$ & 3.0 \\
\hline
\end{tabular}

representative of current farming practices. Feeding times are usually adjusted to avoid ebb/flood maximum when most of the fish activity is concentrated in maintaining position, as well as during slack tides, which may induce suboxic conditions due to low water renewal and increased metabolic activity. Organic carbon content in feed pellets and feces ranges between $49.6 \%$ and $57 \%$, and between $27.6 \%$ and $33 \%$, respectively (Brigolin et al. 2014, Chang et al. 2014). Diet composition may vary from high protein content in summer to favour muscle growth, to high energy content in winter to ensure muscle maintenance. Fish farm densities range between 10 and $17 \mathrm{~kg} \mathrm{~m}^{-3}$ depending on salmonid species, but may reach up to $30 \mathrm{~kg} \mathrm{~m}^{-3}$. The typical salmon grow-out period ranges between 14 and 24 mo for eastern Canada. Based on these data, we forced the simulations by assuming: (1) a twice-per-day feeding schedule (20 min each, starting when the tidal current was decreasing and lower than mean current speed, $\left.u_{\mathrm{WC}, \text { mean }}\right),(2)$ an average carbon content of $52.3 \%$ and $27.9 \%$ in feed pellets and feces, respectively, and (3) a salmon grow-out period of 18 mo. Fish were assumed to be adults and size dependence of fecal output was not incorporated at this stage. Due to this last assumption, a conservative culture density of $8 \mathrm{~kg}$ $\mathrm{m}^{-3}$ was assumed in all simulations.

Feed wastage, as a percentage of feed supply, currently averages $\sim 3 \%$, but may be as high as $8 \%$ (Cromey et al. 2002a, Stucchi et al. 2005, Chang et al. 2014). Assuming the parameters listed in Table 1, the wastage rate of feces and lost feed coming out at the base of the fish cage varies between 15.8 and $27.3 \mathrm{~g}$ $\mathrm{C}_{\text {org }} \mathrm{m}^{-2} \mathrm{~d}^{-1}$ for a feed wastage of $3 \%$ and $8 \%$, respectively. Total waste produced during the entire production cycle is between $163 \mathrm{~kg}$ (3\% feed wastage) and $234 \mathrm{~kg}$ (8\% feed wastage) per tonne of fish produced. Both values are within the range reported in the literature that may reach up to $\sim 1$ tonne of organic waste per tonne of fish produced (Silvert \& Sowles 1996). Feces represent the majority of aquaculture wastes $(76 \%)$ assuming $3 \%$ feed wastage, and decreases to $53 \%$ assuming an $8 \%$ feed wastage. The feed conversion ratio (FCR, dry feed used per wet biomass of fish produced) is estimated to be $\sim 1.2$ due to improvements in feeding technology and feed ingredients (Wang et al. 2012). The FCR calculated from Table 1 (1.45 and 1.47 for the 3 and $8 \%$ feed wastage rates, respectively), was higher than expected for current farming practices; nonetheless, these values are only referential, as they do not consider fish size dependencies of feeding rates and feed properties. 
Dispersion of organic wastes in water column and deposition to sediments

Dispersion of organic wastes in the water column is controlled by water depth, free-stream bottom current speed $\left(u_{\mathrm{WC}}\right)$, and settling velocities of feces and feed pellets (Eq. S13, Table S5) (Stucchi et al. 2005). $u_{\mathrm{WC}}$ followed a semidiurnal tidal cycle $(12 \mathrm{~h}$ and 25 min; Eq. S10 in Table S5), and does not include local variations due to waves or coastal currents, nor more extreme events such as storms. We assumed in all simulations a constant depth of $35 \mathrm{~m}$, no vertical changes in current speed with depth above the benthic boundary layer, and waste particles homogeneously released at the base of the fish cage $(20 \mathrm{~m}$ wide and $15 \mathrm{~m}$ high).

Once at the bottom, the net deposition of organic wastes was controlled by bed shear stress $\left(\tau_{\mathrm{u}}\right)$, and critical shear stress for erosion $\left(\tau_{\mathrm{ce}}\right)$ and deposition $\left(\tau_{\mathrm{cd}}\right)$ (Eqs. S12, S14 and S18 in Table S5), assumed to be equal to 0.0179 and $0.004 \mathrm{~N} \mathrm{~m}^{-2}$, respectively (Cromey et al. 2002b), with no distinction between feces and lost feed. The erosion rate of organic wastes was calculated as a function of the erodibility constant $\left(k_{\text {waste }}\right)$ and the excess shear stress. Resuspension of organic fish wastes occurred when $\tau_{\mathrm{u}}$ was higher than the critical shear stress $\left(\tau_{\mathrm{c}}\right)$ defined for organic wastes. Only particles accumulated at the sediment surface (i.e. the first layer of the depthresolved model) were subject to erosion, not the material within the sediments. Ambient particulate organic carbon (POC) deposition was incorporated directly into sediments as described below, but, unlike aquaculture waste, no resuspension was assumed after deposition.

\section{Diagenetic processes in sediments}

A one-dimensional transport-reaction model was developed to simulate the response of fish farm sediments to organic enrichment. The biologically active sediment layer, where $\mathrm{C}_{\text {org }}$ degradation takes place, was assumed to be equal to $50 \mathrm{~cm}$. The model domain was divided vertically into 60 layers (from the surface down 20 layers of $0.25 \mathrm{~cm}, 10$ layers of $0.5 \mathrm{~cm}, 20$ layers of $1 \mathrm{~cm}$, and 10 layers of $2 \mathrm{~cm}$ ). A finer discretization was defined close to the surface to allow description of strong concentration gradients expected in fish farm sediments.

The general diagenetic equations for solute $\left(C_{i}\right.$, $\mu \mathrm{mol} \mathrm{cm} \mathrm{cm}^{-3}$ solid, Eq. 1) and solid $\left(S_{i}, \mu \mathrm{mol} \mathrm{cm} \mathrm{cm}^{-3}\right.$ porewater, Eq. 2) species is described as follows:

$$
\begin{gathered}
\varphi_{s} \frac{\partial S_{i}}{\partial t}=-\varphi_{s} \frac{\partial}{\partial z}\left(w_{\mathrm{sed}} S_{i}-K_{V} D_{b} \frac{\partial S_{i}}{\partial z}\right)+\sum R\left(S_{i}, C_{i}\right) \\
\varphi \frac{\partial C_{i}}{\partial t}=-\varphi \frac{\partial}{\partial z}\left(w_{\mathrm{pw}} C_{i}+D \frac{\partial C_{i}}{\partial z}\right) \\
+K_{V} v\left(C_{i, 0}-C_{i}\right)+\sum R\left(S_{i}, C_{i}\right)
\end{gathered}
$$

In the above equations, $z$ is the depth below the sediment-water interface $(\mathrm{cm}), \varphi$ is porosity (dimensionless; assumed to be constant in depth and time), $\varphi_{\mathrm{s}}$ is solid porosity $(1-\varphi), w_{\text {sed }}$ is the sediment burial velocity $\left(\mathrm{cm} \mathrm{d}^{-1}\right), w_{\mathrm{pw}}$ is the porewater advection velocity relative to the sedimentwater interface $\left(\mathrm{cm} \mathrm{d}^{-1}\right), C_{i, 0}$ is the concentration of solutes at the sediment-water interface ( $\mu$ mol $\left.\mathrm{cm}^{-3}\right), D_{\mathrm{b}}$ is the bioturbation coefficient $\left(\mathrm{cm}^{2} \mathrm{~d}^{-1}\right)$, $D$ is the molecular diffusion coefficient of solutes $\left(\mathrm{cm}^{2} \mathrm{~d}^{-1}\right), v$ is the exchange velocity of solutes due to bioturbation $\left(\mathrm{cm} \mathrm{d}^{-1}\right)$, and $\sum R\left(S_{i}, C_{i}\right)$ is the net rate of reactions involving solid and solute spe-

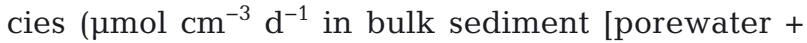
solid]). The complete reaction network is described in Table S1.

External forcing was imposed as variations in tidal current speed $\left(u_{\mathrm{WC}}\right)$, concentration of solute compounds in bottom waters, and solid deposition rates $\left(\mathrm{POC}_{\text {flux,SwI}}\right.$, Waste $\left._{\text {flux,SwI }}, \mathrm{FeOOH}_{\mathrm{dep}}\right)$. Bottomwater concentration of $\mathrm{O}_{2}$ and $\mathrm{SO}_{4}{ }^{2-}$ was calculated at every time step based on the current speed and the concentration difference between the boundary value representing far-field water and the bottom water immediately above sediments (transport processes T1-3, Table S3). The far-field water column had $\mathrm{O}_{2}$ saturation at the given temperature and salinity, constant $\mathrm{SO}_{4}{ }^{2-}$ concentration $(28 \mathrm{mM})$, and no reduced compounds (total $\mathrm{S}^{2-}, \mathrm{Fe}^{2+}$ ). At the lower boundary, flux of solutes was set to zero,

Table 2. Idealized set of biogeochemical reactions (R1 to R9). $\mathrm{R} 1$ and $\mathrm{R} 2$ represent the same redox reaction, i.e. oxic respiration, but located in the water column and sediment,

\begin{tabular}{|c|c|}
\hline \multicolumn{2}{|c|}{ Redox reactions } \\
\hline \multicolumn{2}{|l|}{ Primary } \\
\hline R1-2 & $\mathrm{CH}_{2} \mathrm{O}+\mathrm{O}_{2} \rightarrow \mathrm{CO}_{2}+\mathrm{H}_{2} \mathrm{O}$ \\
\hline R3 & $2 \mathrm{CH}_{2} \mathrm{O}+\mathrm{SO}_{4}{ }^{2-}+2 \mathrm{H}^{+} \rightarrow \mathrm{H}_{2} \mathrm{~S}+2 \mathrm{CO}_{2}+2 \mathrm{H}_{2} \mathrm{O}$ \\
\hline $\mathrm{R} 4$ & $\mathrm{CH}_{2} \mathrm{O}+4 \mathrm{FeOOH}+8 \mathrm{H}^{+} \rightarrow 4 \mathrm{Fe}^{2+}+\mathrm{CO}_{2}+7 \mathrm{H}_{2} \mathrm{O}$ \\
\hline \multicolumn{2}{|c|}{ Secondary } \\
\hline R5 & $\mathrm{H}_{2} \mathrm{~S}+2 \mathrm{O}_{2} \rightarrow \mathrm{SO}_{4}^{2-}+2 \mathrm{H}^{+}$ \\
\hline R6 & $4 \mathrm{Fe}^{2+}+\mathrm{O}_{2}+6 \mathrm{H}_{2} \mathrm{O} \rightarrow 4 \mathrm{FeOOH}+8 \mathrm{H}^{+}$ \\
\hline R7 & $2 \mathrm{FeOOH}+\mathrm{H}_{2} \mathrm{~S}+4 \mathrm{H}^{+} \rightarrow \mathrm{S}^{0}+2 \mathrm{Fe}^{2+}+4 \mathrm{H}_{2} \mathrm{O}$ \\
\hline R8 & $\mathrm{Fe}^{2+}+\mathrm{H}_{2} \mathrm{~S} \rightarrow \mathrm{FeS}+2 \mathrm{H}^{+}$ \\
\hline R9 & $\mathrm{FeS}+\mathrm{S}^{0} \rightarrow \mathrm{FeS}_{2}$ \\
\hline
\end{tabular}
respectively. For associated mathematical and kinetic terms, see Tables S2 \& S4 in the Supplement, respectively 
while solids $\left(\mathrm{C}_{\text {org }}, \mathrm{Fe}^{3+}\right)$ were permanently buried according to burial velocity $\left(w_{\text {sed }}\right)$ and the concentration of solids at depth. The reaction network includes 12 chemical species, 4 elemental cycles $(\mathrm{C}, \mathrm{O}, \mathrm{S}$, and $\mathrm{Fe}$ ), and 9 redox reactions (Table 2). Two $\mathrm{C}_{\text {org }}$ pools with specific degradation rates were considered: ambient $\mathrm{POC}$ and aquaculture organic wastes (feed pellets and feces). Production and net deposition of feces and lost feed were calculated separately, but once in sediments they were considered as a single degradable pool (feed pellets + feces).

In the model, $\mathrm{C}_{\text {org }}$ degradation is carried out by oxic respiration (reaction term R2, Table S2), sulfate reduction (R3) and iron reduction (R4). Maximum degradation rates of $\mathrm{POC}$ and aquaculture wastes were equal to 0.1 and $1 \mathrm{yr}^{-1}$, respectively. The values were chosen based on reported decay rates by Cromey et al. (1998), Brigolin et al. (2009), and Paraska et al. (2014). Denitrification was omitted from the model as its contribution to organic waste degradation is expected to be mostly restricted to initial stages of organic enrichment. Reduced metabolites can be either re-oxidized (R5, R6) or precipitated (R7-R9). Sulfide may precipitate with iron to $\mathrm{S}^{\circ}, \mathrm{FeS}$, or $\mathrm{FeS}_{2}$, with all precipitates being permanently sequestered within sediments. Iron oxides act as intermediates in $\mathrm{H}_{2} \mathrm{~S}$ oxidation (R7), but $\mathrm{O}_{2}$ was the terminal electron acceptor (R5, R6). In the model, iron oxide $\left(\mathrm{FeOOH}_{\mathrm{dep}}\right)$ deposition to sediments was assumed to be constant $\left(175.2 \mu \mathrm{mol} \mathrm{m}{ }^{-2} \mathrm{~d}^{-1}\right.$; Fossing et al. 2004), and affected only by biogeochemical processing, not by resuspension.

The simplification of the reaction network compared to more sophisticated one-dimensional diagenetic models (Boudreau 1996) is a consequence of the long-term goal to perform manageable calculations for decision-makers. Stoichiometric relationships in $\mathrm{C}_{\text {org }}$ degradation were based on Redfield ratios. Oxidant limitation and inhibition terms in redox reactions were expressed through Monod-type hyperbolic functions and reciprocal hyperbolic functions, respectively (Table S4). The concentration of solutes $\left(\mathrm{O}_{2}\right.$, total $\left.\mathrm{S}^{2-}\right)$ and particles $\left(\mathrm{C}_{\text {org }}\right)$ are reported as mean values for the upper $2 \mathrm{~cm}$ of sediments. This distinction is required as monitoring programs of fish farm sites in Canada report sulfide and organic matter content only for this layer (Chang \& Page 2011, NBDELG 2012, NSDFA 2014, Fisheries and Oceans Canada 2015).

Bioturbation. The biologically mediated transport of solutes across the sediment-water interface was simulated according to Hammond \& Fuller (1979).
Their formulation of exchange across the sedimentwater interface is calculated as a function of the difference in solute concentration between sediment and overlying bottom water times the exchange velocity (v) (Eq. 2). We chose this formulation to reduce the uncertainty of separately modelling biodiffusion and bioirrigation (non-local exchange) processes. Bioturbation of solids was simulated using a biodiffusion coefficient $\left(D_{\mathrm{b}}\right)$.

In addition, a controlling factor of biological transport $\left(K_{\mathrm{V}}\right)$ was added to account for detrimental effects of toxic $\mathrm{H}_{2} \mathrm{~S}$ concentration on macrofaunal activity (Eq. S16, Table S5). In the model, macrofaunal communities become inactive with no bio-transport at sulfide concentrations in sediments $>5000 \mu \mathrm{M}$ (Brigolin et al. 2009). The $K_{\mathrm{v}}$ factor (0 to 1 ) expresses the current state of faunal bioturbation and how quickly they recover or become inactive according to benthic stress.

Microbial dynamics. Microbial activity $\left(M_{\mathrm{SL}}\right)$ was explicitly simulated in the model. Its incorporation was required to account for the expected increase in microbial activity in fish farm sediments. According to Vezzulli et al. (2002) and La Rosa et al. (2001), bacterial abundance may increase up to 3-fold in sediments beneath fish farm cages. Microbial activity in sediments, including aerobic and anaerobic metabolism, was explicitly modelled assuming facultative metabolism and a discrete logistic growth model according to Talin et al. (2003). The growth rate was jointly determined by the intrinsic growth rate $\left(\mathrm{d}^{-1}\right)$, which is proportional to $\mathrm{C}_{\text {org }}$ degradation (R2 to R4, Table S2), and a variable carrying capacity that depends on $\mathrm{C}_{\text {org }}$ availability (Eq. S9, Table S1). The relative change in microbial activity is reduced as its biomass increases, approaching zero as the carrying capacity is reached. Formulation of Talin et al. (2003) was unchanged except by the incorporation of a partitioning factor of microbial activity $\left(\mathrm{PF}_{\mathrm{M}}\right)$ among different metabolic pathways (see R2-R4 in Table S2 and Eqs. S20-S22 in Table S5). $M_{\mathrm{SL}}$ in reaction terms R2-R4 (Table S2) is dimensionless, and may be viewed as an enhancement factor of $\mathrm{C}_{\text {org }}$ degradation. $\partial M / \partial \mathrm{t}$, the rate of change of microbes $(M)$ over time, has units of $\mathrm{d}^{-1}$.

Parameterization. Most model parameters were taken from the literature (reaction rates, half-saturation constants, stoichiometric coefficients, and temperature dependence coefficients), and some were adjusted manually within the range of published data, in order to correctly reproduce field observations (Table S6 in the Supplement). 
POC production and export to bottom waters

Ambient POC deposition was assumed to be constant and equal to $0.42 \mathrm{~g} \mathrm{C}_{\text {org }} \mathrm{m}^{-2} \mathrm{~d}^{-1}$. This value is within the reported range for shallow coastal environments in eastern Canada (Hargrave 1994, 1995, Hatcher et al. 1994, Burt et al. 2013), and is considered typical of oligotrophic to mesotrophic coastal systems (Eyre \& Ferguson 2009).

\section{Sensitivity analysis}

The sensitivity of state variables to changes in model parameters and forcing conditions was evaluated following Jørgensen \& Bendoricchio (2001) and Chapelle et al. (2000). The parameters tested include boundary conditions, transport and reaction parameters, saturation and inhibition coefficients, sedimentary coefficients, and those related to benthic activity. A sensitivity index IS\% was calculated as:

$$
\mathrm{IS} \%=\frac{100}{p} * \frac{1}{n} \sum_{i=1}^{n} \frac{x_{i}-x_{i}^{r e f}}{x_{i}^{r e f}}
$$

where $p$ is the percentage of parameter variation $( \pm 10 \%)$ in relation to the range of values described for each parameter, and $\left(x_{i}-x_{i}^{r e f}\right)$ represents the change in the state variable $\left(x_{i}\right)$ in relation to a reference value $\left(x_{i}^{r e f}\right)$. The sensitivity to changes in model parameterization was tested for 2 key variables: $\mathrm{O}_{2}$ consumption rates (chemical and biological) and sulfide concentration in surface sediments. Main results of the sensitivity analysis are reported in the first section of the 'Results', and complementary data are presented in the Supplement (Fig. S2 and Table S7). In addition, a mass balance calculation of POC, $\mathrm{O}_{2}, \mathrm{H}_{2} \mathrm{~S}$ and $\mathrm{Fe}$ (III) at steady-state was calculated to ensure mass conservation.

\section{Geochemical indices}

Two geochemical indicators were monitored in simulations: total sulfide (total $\mathrm{S}^{2-}$ ) concentration in sediments, and the degradation efficiency, defined as the ratio between daily-averaged $\mathrm{C}_{\text {org }}$ degradation rates and gross deposition rates (expressed as a percentage when multiplied by 100). $\mathrm{C}_{\text {org }}$ degradation efficiency was calculated by integration of time series of gross deposition (i.e. particles arriving at the sediment surface) and depth-integrated degradation rates for the periods of interest (e.g. throughout the fish farm cycle). Values that are lower than 1 can be explained either by the accumulation of organic wastes in non-dispersive conditions or by erosion in dispersive conditions.

\section{Assimilative capacity of fish farm organic wastes}

The assimilative capacity of sediments was determined based on their ability to oxidize organic carbon and prevent the development of reducing conditions, as shown conceptually in Fig. 1. It is assumed that total $\mathrm{C}_{\text {org }}$ degradation (aerobic and anaerobic, black line) increases with $\mathrm{C}_{\text {org }}$ deposition. As waste net deposition increases, the relative contribution of oxic respiration (dotted black line) to total $\mathrm{C}_{\text {org }}$ degradation is expected to decrease as a result of increased anaerobic degradation. In the present study, the assimilative capacity of organic wastes was defined as the gross $C_{\text {org }}$ deposition rate $\left(\mathrm{g} \mathrm{m}^{-2} \mathrm{~d}^{-1}\right)$ that can be degraded in a particular sedimentary environment without leading to sulfide concentration above regulated limits in Canada (sulfide $>1500 \mu \mathrm{M}$ in the upper

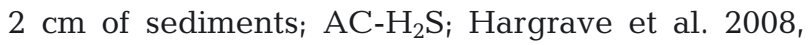
NBDENV 2012, NSDFA 2014).

Based on the former definition and associated criteria, environmental management of aquaculture sites is considered successful if gross deposition of $\mathrm{C}_{\text {org }}$, including ambient and fish farm loading, is below the

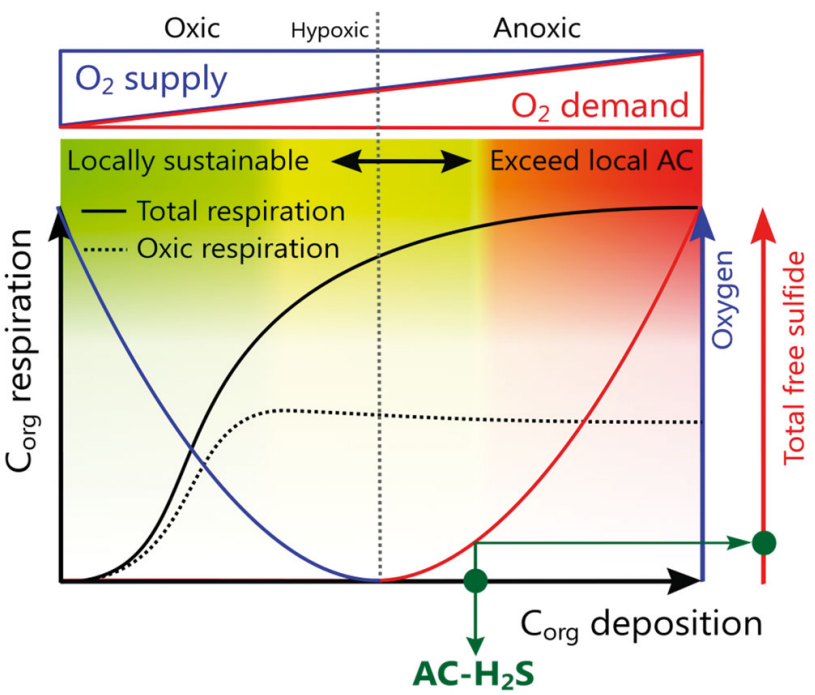

Fig. 1. Conceptual representation of assimilative capacity $\left(\mathrm{AC}-\mathrm{H}_{2} \mathrm{~S}\right)$ of organic-rich solid wastes in sediments underlying fish farm cages. Total and oxic respiration are represented by black solid and dashed lines, respectively, while $\mathrm{O}_{2}$ and total $\mathrm{S}^{2-}$ concentrations are represented by blue and red lines, respectively. The green circles represent the highest $\mathrm{C}_{\text {org }}$ loading rate (particulate organic carbon + organic wastes, net value) feasible to be assimilated by benthic communities while preventing toxic sulfide concentration to rise above the regulatory limit in Canada 
local sediment assimilative capacity. Assimilative capacity is reported using gross instead of net deposition (deposition - erosion) to be able to compare model results with empirical and model estimations of sediment assimilative capacity and waste deposition.

Assimilative capacity was predicted based on scenario analysis, but also more formally using constrained optimizations. Optimization analysis consisted of the iterative adjustment of wastage rates (fish cage outputs) to produce gross deposition at assimilative capacity. We stress that this criterion allows for some anaerobic degradation without exceeding $\mathrm{AC}-\mathrm{H}_{2} \mathrm{~S}$.

The estimation of $\mathrm{AC}-\mathrm{H}_{2} \mathrm{~S}$ throughout constrained optimization implies that microbial activity $\left(M_{\mathrm{SL}}\right)$ has steady growth to reach maximum capacity for degrading organic wastes $(\partial M / \partial \mathrm{t}=0)$. To investigate the implications of the latter assumption we compared constrained values (steady-state solution) with results of scenario analysis (non-steady state solution).

\section{Scenario simulations}

Simulations were carried out in 4 hydrodynamic scenarios covering poorly flushed (low shear stress) to well-flushed conditions (high shear stress). Table 3 specifies the hydrodynamic conditions and the sediment parameters for each scenario, identified as high and low deposition (H-DEPO and L-DEPO), and low and high dispersion (L-DISP and H-DISP), respectively. Average free-stream bottom current speeds $\left(u_{\mathrm{WC}, \text { mean }}\right)$ were equal to $3,5,9$, and $11 \mathrm{~cm} \mathrm{~s}^{-1}$, respectively. Maximum current speeds exerted by tides were equal to $6.2,10.3,18.5$, and $22.6 \mathrm{~cm} \mathrm{~s}^{-1}$, respectively. Dispersive from non-dispersive (depositional) sites are differentiated based on the mean tidal current $\left(u_{\mathrm{WC} \text {,mean }}\right)$, the threshold being $9.5 \mathrm{~cm} \mathrm{~s}^{-1}$, the free-stream speed at which resuspension of solid wastes is initiated (corresponding to $\tau_{c}>\tau_{u}$ ). On aver- age, $u_{\mathrm{WC}}$ was above the threshold current speed for resuspension during $0 \%$ (H-DEPO), 17.6\% (L-DEPO), $49.1 \%$ (L-DISP), and $55.1 \%$ (H-DISP) of a full tidal cycle. Sediment porosity was constant at 0.8 in all simulations.

Simulations of fish farm activities and deposition of organic wastes were initiated once steady-state conditions were achieved in sediments exposed to ambient $\mathrm{C}_{\text {org }}$ deposition. Total waste production for the entire farming cycle $\left(\mathrm{g} \mathrm{C}_{\text {org }} \mathrm{m}^{-2}\right)$, and its fate once released to the environment (deposition, erosion, degradation, burial, and accumulation in surface sediments), was calculated by integration of the resulting time series. In order to represent the broad spectrum of husbandry practices at the fish farm, we ran simulations assuming feed wastage between $3 \%$ (highly efficient) and $8 \%$ (inefficient), and either a constant wastage rate (i.e. no diel variation in feeding rate, specifically in constrained optimizations) or twice-per-day feeding for $20 \mathrm{~min}$ each (in scenario analysis). In the latter case, lost feed to the environment only occurs during feeding time.

Ambient POC deposition (non-farm) was assumed to be equal to $0.42 \mathrm{~g} \mathrm{C}_{\text {org }} \mathrm{m}^{-2} \mathrm{~d}^{-1}$ in all scenarios (Table 3). No resuspension was considered for ambient deposits. Similarly, sediment properties, including porosity and burial velocity, were assumed to be constant among scenarios. Only the $\mathrm{O}_{2}$ concentration in bottom waters was free to vary as described previously.

\section{RESULTS}

\section{Mass conservation and sensitivity of variables to model parameterization}

The model is stable, that is to say, it does not collapse due to errors such as round-off or discretization, and provides reasonable results across a wide range

Table 3. Hydrodynamic and sedimentary parameters for scenario analysis. H-DEPO and L-DEPO: high and low deposition; L-DISP and H-DISP: low and high dispersion; $Z_{\mathrm{WC}}$ : water column depth below the fish cage; $\mathrm{C}_{\text {org }}$ : organic carbon

\begin{tabular}{|lcccc|}
\hline & H-DEPO & L-DEPO & L-DISP & H-DISP \\
\hline Average free-stream bottom current $\left(\mathrm{cm} \mathrm{s}^{-1}\right), u_{\mathrm{WC}, \text { mean }}$ & $3.1 \pm 2.2$ & $5.1 \pm 3.6$ & $9.2 \pm 6.5$ & $11.3 \pm 8.0$ \\
Maximum bottom current speed $\left(\mathrm{cm} \mathrm{s}^{-1}\right)$ & 6.2 & 10.3 & 18.5 & 22.6 \\
Sediment porosity, $\varphi$ & 0.8 & 0.8 & 0.8 & 9.8 \\
Percent dispersion based on $u_{\mathrm{WC} \text {,mean }}$ and $Z_{\mathrm{WC}}$ : & & 85.3 & 93.4 \\
$\quad$ Non-consumed feed pellets $(\%)$ & 94.1 & 97.9 & 99.2 & 95.1 \\
Feces $(\%)$ & 0.42 & 0.42 & 0.42 \\
Ambient deposition $\left(\mathrm{g} \mathrm{C}_{\text {org }} \mathrm{m}^{-2} \mathrm{~d}^{-1}\right)$ & & & 0.42 \\
\hline
\end{tabular}


of environmental conditions and rapid changes in $\mathrm{C}_{\text {org }}$ deposition. Mass conservation was achieved for solutes and particulate compounds in steady-state conditions. Results of the sensitivity analysis showed that $\mathrm{O}_{2}$ consumption rates, particularly chemical demand, were highly sensitive to the rate constant for sulfide oxidation by $\mathrm{O}_{2}\left(k_{\text {Total }} \mathrm{S}_{\mathrm{SL}, 0 \times 1}^{2-}\right)$ (Fig. S2, Table S7), which can vary widely from $10^{5}$ to $10^{15} \mathrm{l} \mathrm{mol}^{-1} \mathrm{yr}^{-1}$ (Katsev et al. 2004). As expected, $\mathrm{O}_{2}$ consumption rates (total $\mathrm{O}_{2}$ uptake, TOU) were also sensitive to the $\mathrm{O}_{2}$ concentration in bottom water $\left(\left[\mathrm{O}_{2}, \mathrm{WC}, \mathrm{BC}\right]\right)$, the maximum decay rates of $\mathrm{C}_{\text {org }}$ in sediments $\left(R_{\mathrm{POC}, S \mathrm{SL}}^{\max }\right)$, and the burial rate of particles within the sediment $\left(W_{\text {sed }}\right)$. Total $\mathrm{S}^{2-}$ concentration was sensitive to the specific oxidation rate of POC $\left(R_{\mathrm{POC}, \mathrm{SL}}^{\max }\right)$, and the half saturation constant for sulfate reduction $\left(K_{\mathrm{S}, \mathrm{SR}}\right)$. Except for $k_{\text {Total }} \mathrm{S}_{\mathrm{SL}, 0 \times 1}^{2-}$, the sensitivity of the state variables in all cases was lower than $5 \%$, which indicates the robustness of the model to changes in forcing conditions and parameterization (Hochard et al. 2010).

\section{Sediment metabolism in ambient conditions}

Under ambient deposition, model predictions show that sediment $\mathrm{O}_{2}$ demand does not affect the $\mathrm{O}_{2}$ concentration significantly in bottom water under any scenario. As a result, no differences in the benthic processes were predicted among scenarios when exposed to ambient deposition. We recall that no resuspension was allowed for ambient deposits. TOU at steady state was equal to $3.7 \mathrm{mmol} \mathrm{m}^{-2} \mathrm{~d}^{-1}$, dominated by oxic respiration $(61 \%)$. Chemical $\mathrm{O}_{2}$ demand (COD) contributed the remaining $39 \%$, being largely dominated by sulfide reoxidation (97\%). Degradation efficiency was equal to $84 \%$; the remaining fraction was buried within sediments $(16 \%)$. Sulfate reduction dominated $\mathrm{C}_{\text {org }}$ degradation $(85 \%)$, followed by oxic respiration (14\%). Sulfide concentration predicted in surface sediments (upper $2 \mathrm{~cm}$ ) was equal to $859 \mu \mathrm{M}$. Expressed as \% solids ( $\mathrm{g} \mathrm{C}_{\text {org }} \mathrm{g}$ dry sediment $\left.^{-1} \times 100\right), C_{\text {org }}$ concentration under ambient conditions was equal to $0.82 \%$.

\section{Sediment dynamics during fish farm operations}

The impact of organic enrichment on TOU, the accumulation of reduced by-products $\left(\mathrm{H}_{2} \mathrm{~S}, \mathrm{Fe}^{2+}\right)$, and depletion of oxidants in sediments varied depending on wastage rate from the fish cage and hydrodynamic conditions (H-DEPO to H-DISP).

\section{Transient dynamics}

Fig. 2 exemplifies the transient response of sediments exposed to fish farm wastes in the H-DEPO scenario. The simulation was initiated from ambient deposition and assuming a single fish farm cycle according to Table 1, twice-per-day feeding, and a $3 \%$ feed wastage. The daily-accumulated wastage rate under these conditions was equal to $19.4 \mathrm{~g} \mathrm{C}_{\text {org }}$ $\mathrm{m}^{-2} \mathrm{~d}^{-1}$, of which $75 \%$ corresponded to feces and $25 \%$ to lost feed. As observed in Fig. 2A, gross deposition of organic wastes varied significantly within the day as a result of changes in dispersion of particle wastes due to tidal currents, as well as variations in waste production (maximum of $\sim 34 \mathrm{~g} \mathrm{~m}^{-2} \mathrm{~d}^{-1}$ during feeding time).

TOU increased significantly after exposure to organic wastes (up to $15.8 \mathrm{mmol} \mathrm{O}_{2} \mathrm{~m}^{-2} \mathrm{~d}^{-1}$ ). As observed in Fig. 2B, oxic respiration contributed to the majority of $\mathrm{O}_{2}$ consumption throughout the farming cycle. This occurred at the expense of the COD, which decreased during the same period, from $\sim 1.4 \mathrm{mmol} \mathrm{m}^{-2} \mathrm{~d}^{-1}$ in ambient conditions to less than $0.5 \mathrm{mmol} \mathrm{m}^{-2} \mathrm{~d}^{-1}$ under fish farm operation. Two reactions in the model contribute to COD: total $\mathrm{S}^{2-}$ oxidation and $\mathrm{Fe}^{2+}$ oxidation. Similar to the sediments exposed to ambient deposition, COD in fish farm sediments was largely dominated by sulfide oxidation.

Expressed as \% solids (i.e. $\mathrm{g} \mathrm{C}_{\text {org }}$ g solid ${ }^{-1} \times 100$ ), the $\mathrm{C}_{\text {org }}$ concentrations (POC plus organic wastes) in surface sediments by completion of the fish farm cycle was equal to $2.6 \%$ in the H-DEPO scenario (Table 4).

After cessation of organic waste deposition (fish harvest), sediment recovery was characterized by a slow decrease of oxic respiration, and of the content of sulfide and organic matter. The recovery of oxic and chemical $\mathrm{O}_{2}$ demand to background levels in the H-DEPO scenario (Fig. 2B) lasts more than a year according to simulations; nonetheless, this model does not consider the occurrence of stochastic events, such as winter storms that may accelerate sediment recovery.

The degradation efficiency, defined as the ratio between organic waste degradation and gross deposition, increased significantly throughout the farming cycle in H-DEPO as a result of sustained increases in microbial activity and sedimentary $\mathrm{C}_{\text {org }}$ (Fig. 3A). This increase in degradative capacity over time occurred despite detrimental effects of organic enrichment on bioturbation activity. The greatest changes in degradation efficiency of organic wastes were predicted in the H-DEPO scenario, from values 

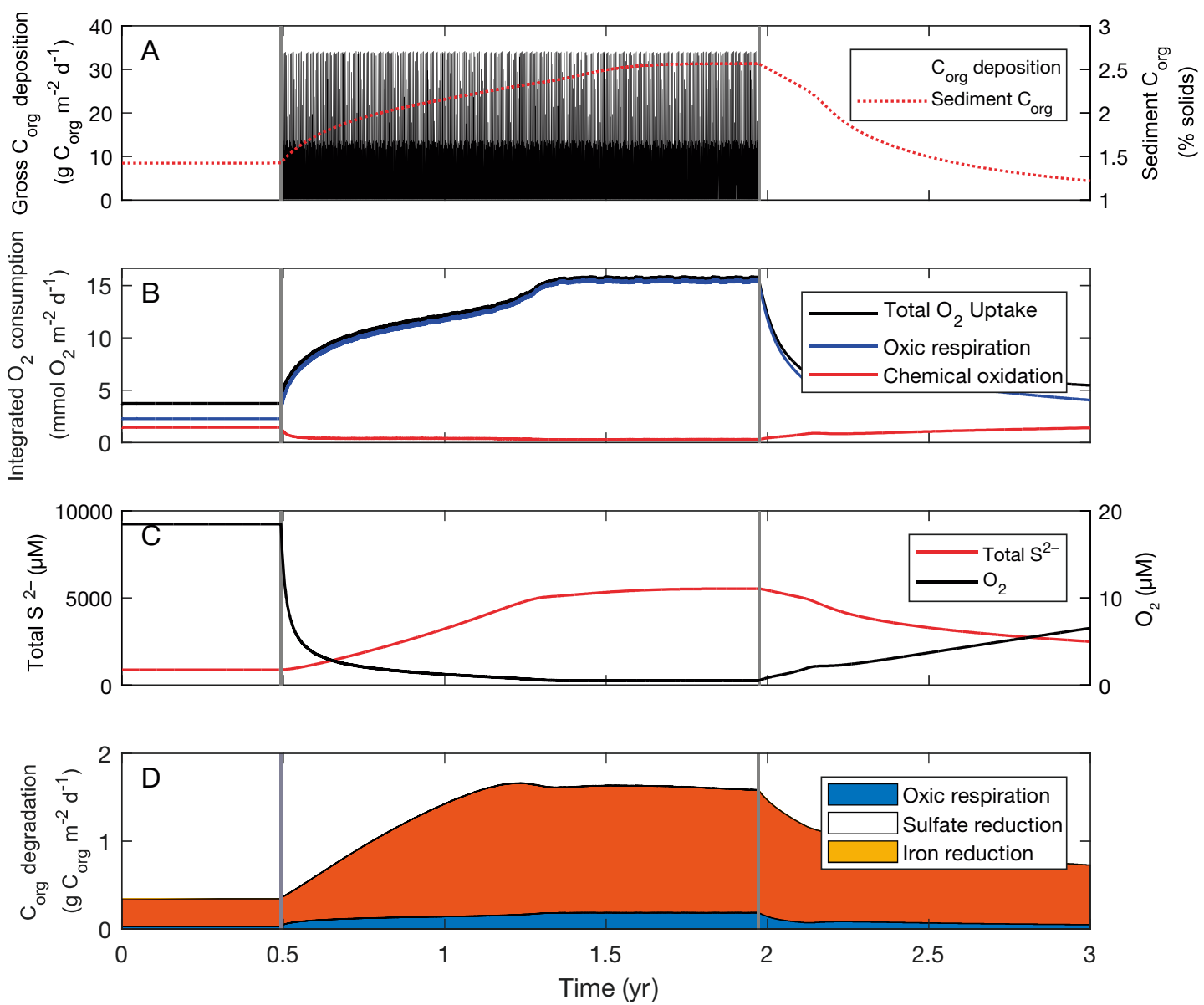

Fig. 2. Forcing and state variables in a temporal simulation of organic waste processing in sediments underlying a fish farm cage according to parameters of Table 1 and assuming a feed wastage of $3 \%$. Vertical gray lines at 0.5 and 1.97 yr delineate the farming cycle. This simulation corresponds to the high deposition case (H-DEPO) defined in Table 3. Parameters of the simulation are as follows: length of fish farm production cycle, $18 \mathrm{mo}$; mean free-stream bottom current speed, $3.1 \pm 2.2 \mathrm{~cm} \mathrm{~s}^{-1}$; daily accumulated wastage rate (feces plus lost feed), $19.4 \mathrm{~g} \mathrm{C}_{\text {org }} \mathrm{m}^{-2} \mathrm{~d}^{-1}, \mathrm{C}_{\text {org }}$ : organic carbon; average daily organic waste deposition (gross value), $2.3 \mathrm{~g} \mathrm{C}_{\mathrm{org}} \mathrm{m}^{-2} \mathrm{~d}^{-1}$. (A) Gross $\mathrm{C}_{\text {org }}$ deposition and $\mathrm{C}_{\text {org }}$ concentration in sediments (particulate organic carbon + organic wastes). Peaks observed in deposition rates are caused by increased wastage rate during feeding time. (B) The contribution of oxic respiration and chemical $\mathrm{O}_{2}$ demand to vertically integrated $\mathrm{O}_{2}$ consumption rates. (C) Sulfide and $\mathrm{O}_{2}$ concentration in surface sediments (upper $2 \mathrm{~cm}$ ). (D) $\mathrm{C}_{\text {org }}$ degradation in sediments and contribution of aerobic and anaerobic degradation pathways

close to zero at the beginning of the farming cycle to $\sim 30 \%$ at completion. Degradation efficiency was close to zero in the L- and H-DISP scenarios due to almost null net deposition of organic wastes.

Degradation efficiency was calculated based on daily averaged organic waste degradation and gross deposition rates. This was required to eliminate strong variations in degradation efficiency caused by changes in organic waste deposition within the day (due to changes in currents and feeding time). The remaining variation observed in Fig. 3A, particularly in the DEPO scenarios, is caused by variations in the daily accumulated $\mathrm{C}_{\text {org }}$ deposition rates due to the daily offset of the simulated tidal current $\left(\sim 25 \operatorname{min~}^{-1}\right)$.
Fig. 4 shows the evolution of microbial activity, which increased through the fish farm cycle, following the dynamic of the $\mathrm{C}_{\text {org }}$ concentration. Microbial activity was predicted to enhance $\mathrm{C}_{\text {org }}$ degradation rates up to 3 -fold compared to simulations without the microbial sub-model. This agrees with observations by Vezzulli et al. (2002) and La Rosa et al. (2001).

\section{Integrated processes}

Similar patterns are observed when benthic processes are integrated over the entire farming cycle (18 mo; Fig. 5). The percent of organic wastes reach- 

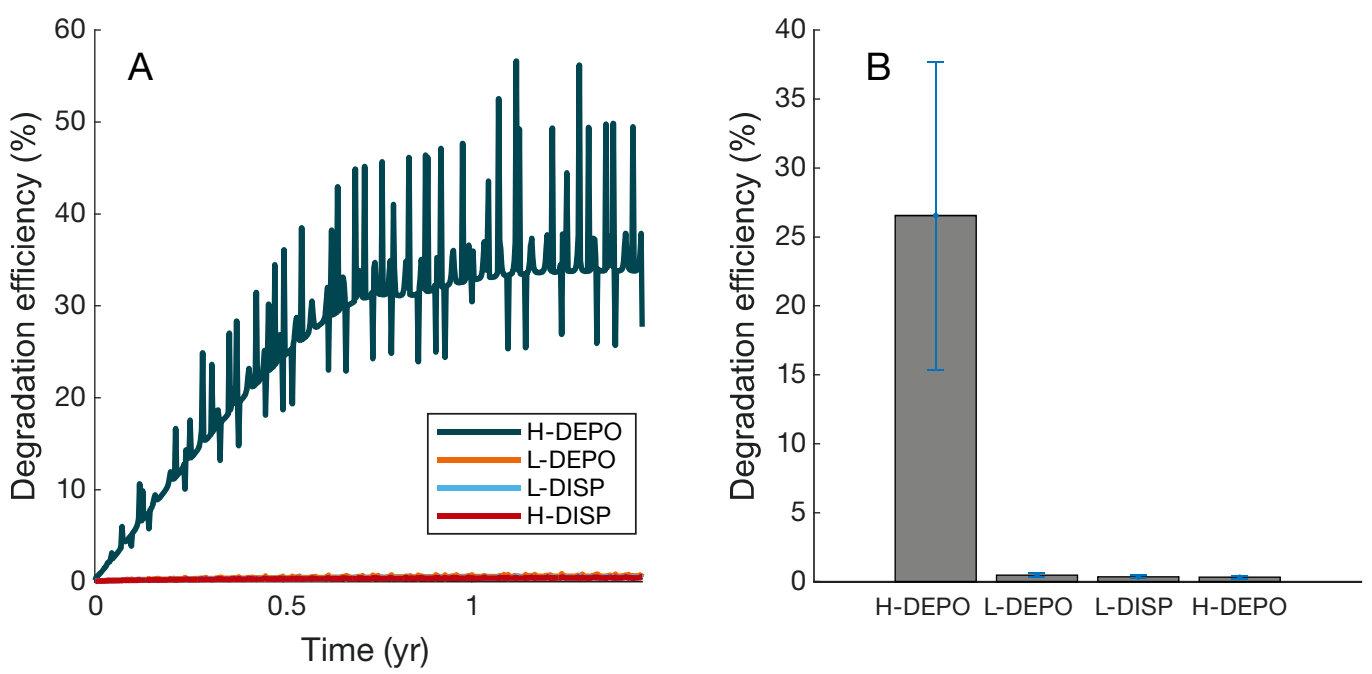

Fig. 3. (A) Evolution of degradation efficiency of organic wastes (not ambient deposits) throughout a single fish farm production cycle according to parameters of Table 1. Simulations were carried out assuming a feed wastage of $3 \%$, twice-per-day feeding (for $20 \mathrm{~min}$ each), and a constant water depth of $20 \mathrm{~m}$ below the fish cage (35 $\mathrm{m}$ in total). Simulations are presented for 4 different hydrodynamic scenarios: high and low deposition (H- and L-DEPO) and low and high dispersion (L- and H-DISP). (B) Mean degradation efficiency of organic wastes for each hydrodynamic scenario defined in Table 3

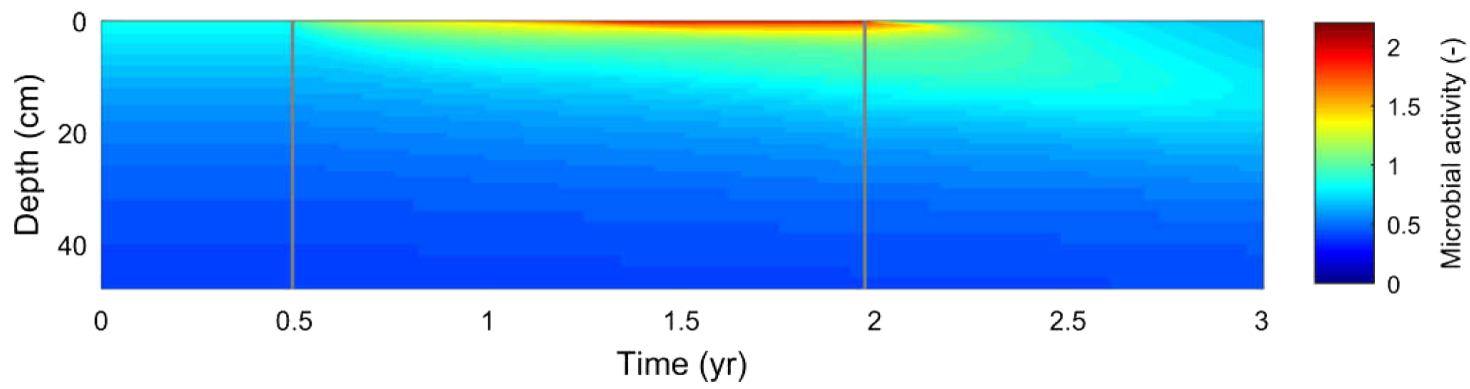

Fig. 4. Microbial activity (dimensionless) in sediments exposed to organic enrichments according to parameters of Table 2 and assuming a feed wastage of $3 \%$. Vertical lines at 0.5 and $1.97 \mathrm{yr}$ delineate the farming cycle. This simulation corresponds to the high deposition case (H-DEPO) defined in 'Materials and methods'

ing sediments (gross values) varied from $\sim 22 \%$ in $\mathrm{H}$ DEPO $\left(2.3 \mathrm{~kg} \mathrm{~m}^{-2}\right)$ to $\sim 9.0 \%$ in H-DISP $\left(0.9 \mathrm{~kg} \mathrm{~m}^{-2}\right)$. The total amount of waste generated throughout the farming cycle $(540 \mathrm{~d})$ was equal to $10.5 \mathrm{~kg} \mathrm{~m}^{-2}$ (assuming a $3 \%$ feed wastage and parameters listed in Table 1). Ambient deposition in the same period was equal to $0.23 \mathrm{~kg} \mathrm{C}_{\text {org }} \mathrm{m}^{-2}$.

As observed in Fig. 5A, the dispersion of organic wastes in the water column was considerable and increased with mean tidal current (higher at $\mathrm{H}$ DISP). Mass erosion was low at both hydrodynamic extremes (H-DEPO and H-DISP), either because most of the time current speed was below critical current speed for resuspension (in H-DEPO), or because little organic material was available for resuspension (in H-DISP). The highest resuspension was predicted under the intermediate hydrodynamic scenarios (LDEPO and L-DISP), where the exchange of solids at the sediment surface was the highest.
The dispersion of solid wastes in the water column was the major factor controlling the fate of solid wastes. Within the farming cycle, sediment burial at the lower boundary $(50 \mathrm{~cm})$ was negligible in all scenarios, and accumulation of organic wastes was only predicted in L-DEPO $\left(1.68 \mathrm{~kg} \mathrm{~m}^{-2}\right)$. Erosion played a significant role in the fate of solid wastes after deposition, particularly in L-DEPO). Erosion in Land H-DISP was lower compared to L-DEPO due to the relatively higher predicted dispersion in the water column. Hereafter, we do not discuss organic waste degradation in L- and H-DISP, as net deposition was negligible in both scenarios (Fig. 5A). The latter does not imply that the net deposition of organic wastes may have a significant impact on sediment geochemistry at different farming (e.g. higher density) or hydrodynamic regimes (e.g. shallower depth). Accumulated over the entire fish farm production cycle, $26.2 \%$ and $0.5 \%$ of predicted gross 
Table 4. Benthic processes at fish farm sediments under 4 hydrodynamic scenarios: high and low deposition (H- and L-DEPO) and low and high dispersion (L- and H-DISP). Simulations were carried out assuming a representative fish farm production cycle according to Table 1, including a feed wastage of $3 \%$, twice-per-day feeding (for $20 \mathrm{~min}$ each), and a constant water depth of $20 \mathrm{~m}$ below the fish cage (35 $\mathrm{m}$ in total). Wastage rate including feces and lost feed was equal to $19.4 \mathrm{~g} \mathrm{C}_{\text {org }}$ $\mathrm{m}^{-2} \mathrm{~d}^{-1}$. Degradation efficiency was calculated based on daily averaged $\mathrm{C}_{\text {org }}$ degradation and gross deposition rates. Gross $\mathrm{C}_{\text {org }}$ deposition rates represent the flux that reaches sediments prior resuspension, but after dispersion in the water column. The surface concentrations of $\mathrm{C}_{\text {org }}, \mathrm{O}_{2}$, and total $\mathrm{S}^{2-}$ are reported for the upper $2 \mathrm{~cm}$ of sediments. Mean values were calculated considering the entire farming cycle (540 d). Values of waste production, deposition, and degradation in fish farm sediments are accumulated values for the entire fish farm cycle

\begin{tabular}{|c|c|c|c|c|}
\hline & H-DEPO & L-DEPO & L-DISP & H-DISP \\
\hline Waste production $\left(\mathrm{kg} \mathrm{m}^{-2}\right)$ & 10.5 & 10.5 & 10.5 & 10.5 \\
\hline Gross waste deposition $\left(\mathrm{kg} \mathrm{m}^{-2}\right)$ & 2.3 & 1.6 & 1.1 & 0.9 \\
\hline Organic waste degradation $\left(\mathrm{kg} \mathrm{m}^{-2}\right)$ & 0.60 & 0.08 & 0.03 & 0.03 \\
\hline Degradation efficiency (\%) & 26.1 & 0.5 & 0.3 & 0.3 \\
\hline Mean total $\mathrm{S}^{2-}(\mu \mathrm{M})$ & 3952.7 & 810.7 & 827.2 & 837.5 \\
\hline Maximum total $\mathrm{S}^{2-}(\mu \mathrm{M})$ & 5527.8 & 851.4 & 862.3 & 870.3 \\
\hline Mean $\mathrm{C}_{\text {org }}(\%$ solids $)$ & 2.3 & 1.0 & 1.1 & 1.1 \\
\hline Maximum $\mathrm{C}_{\text {org }}(\%$ solids $)$ & 2.6 & 1.2 & 1.3 & 1.4 \\
\hline Mean $\mathrm{O}_{2}(\mu \mathrm{M})$ & 1.4 & 24.2 & 22.8 & 22.1 \\
\hline Minimum $\mathrm{O}_{2}(\mu \mathrm{M})$ & 0.5 & 20.8 & 19.7 & 19.1 \\
\hline
\end{tabular}

waste deposits were degraded locally within the farming cycle in H-DEPO and L-DEPO, respectively (Figs. 4B \& 5A, Table 4).

As observed in Fig. 5B, sulfate reduction was the dominant pathway of organic waste degradation in non-dispersive conditions, accounting for $89 \%$ (HDEPO) and $94 \%$ (L-DEPO) of total $\mathrm{C}_{\text {org }}$ degradation.

\section{Assimilative capacity}

Scenario analysis

Scenario analyses were carried out assuming a fish farm cycle according to Table 1, twice-perday feeding, and a percent feed wastage between zero (ambient deposition) and $8 \%$. All simulations were initiated under ambient conditions, implying no previous exposure to organic wastes. Fig. 6 shows gross deposition rates and benthic processes as a function of the percent feed wastage for the different hydrodynamic scenarios described in Table 3.

Gross deposition rates increased with percent feed wastage, reaching up to $6.4 \mathrm{~g} \mathrm{C} \mathrm{m}^{-2} \mathrm{~d}^{-1}$ in $\mathrm{H}$ DEPO when assuming an $8 \%$ feed wastage (Fig. 6A). Net deposition for $\mathrm{H}$-DEPO ranged between $2.5 \mathrm{~g}$ $\mathrm{C} \mathrm{m}^{-2} \mathrm{~d}^{-1}$ ( $0.8 \%$ feed wastage) and $3.6 \mathrm{~g} \mathrm{C} \mathrm{m}^{-2} \mathrm{~d}^{-1}$ ( $8 \%$ feed wastage; Fig. $6 \mathrm{~B}$ ). These values were considerably higher than net deposition (including the fixed ambient deposition) predicted at $\mathrm{AC}-\mathrm{H}_{2} \mathrm{~S}$ (0.62 $\mathrm{g} \mathrm{C}_{\text {org }} \mathrm{m}^{-2} \mathrm{~d}^{-1}$; Table 5). Net deposition of organic wastes for L-DEPO to H-DISP was negligible regarding the variations in wastage rate. Fish density
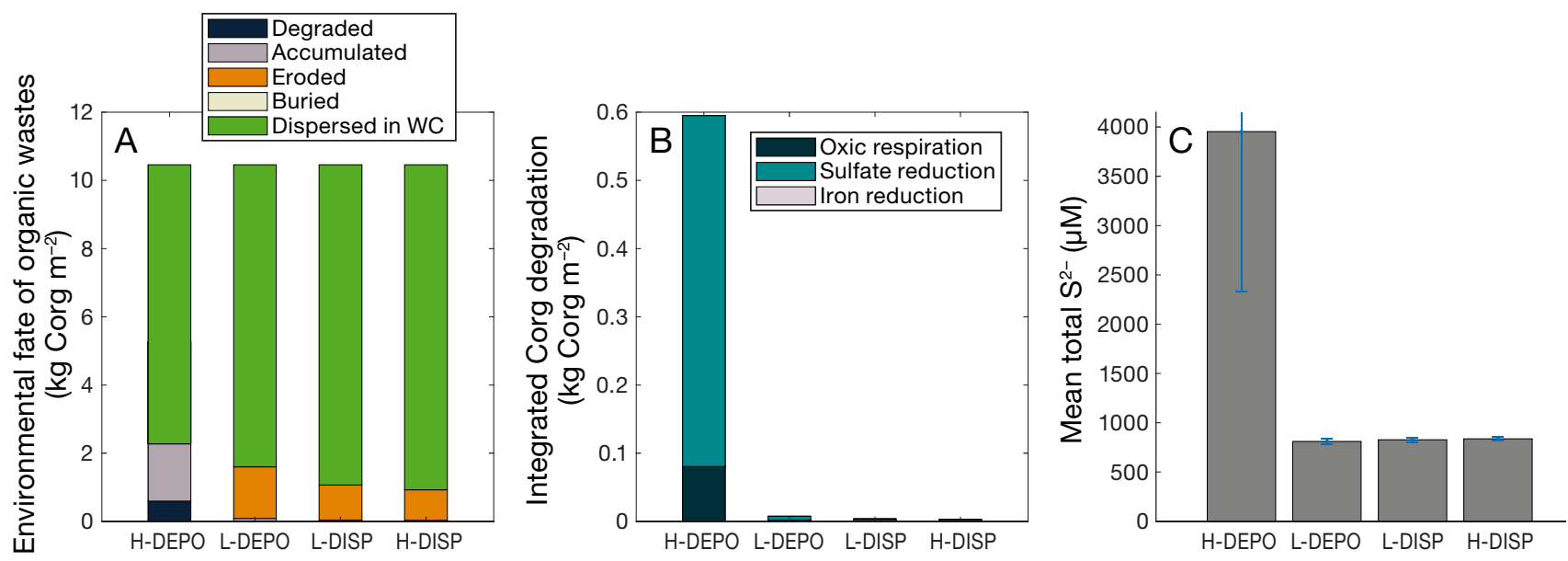

Fig. 5. Integrated benthic processes calculated for a representative fish farm production cycle according to Table 1. Simulations were carried out assuming a feed wastage of $3 \%$, twice-per-day feeding (for 20 min each), and a constant water depth of $20 \mathrm{~m}$ below the fish cage ( $35 \mathrm{~m}$ in total). Simulations are presented for 4 different hydrodynamic scenarios covering poorly (HDEPO) to well-flushed aquaculture sites (H-DISP) according to Table 3. (A) The fate of organic wastes released at the base of the fish cage. WC: water column. (B) Integrated total $\mathrm{C}_{\text {org }}$ degradation and contribution of different degradation pathways to organic waste degradation (not ambient particulate organic carbon). (C) Mean $( \pm 1 \mathrm{SD})$ total $\mathrm{S}^{2-}$ concentration throughout the farming cycle 

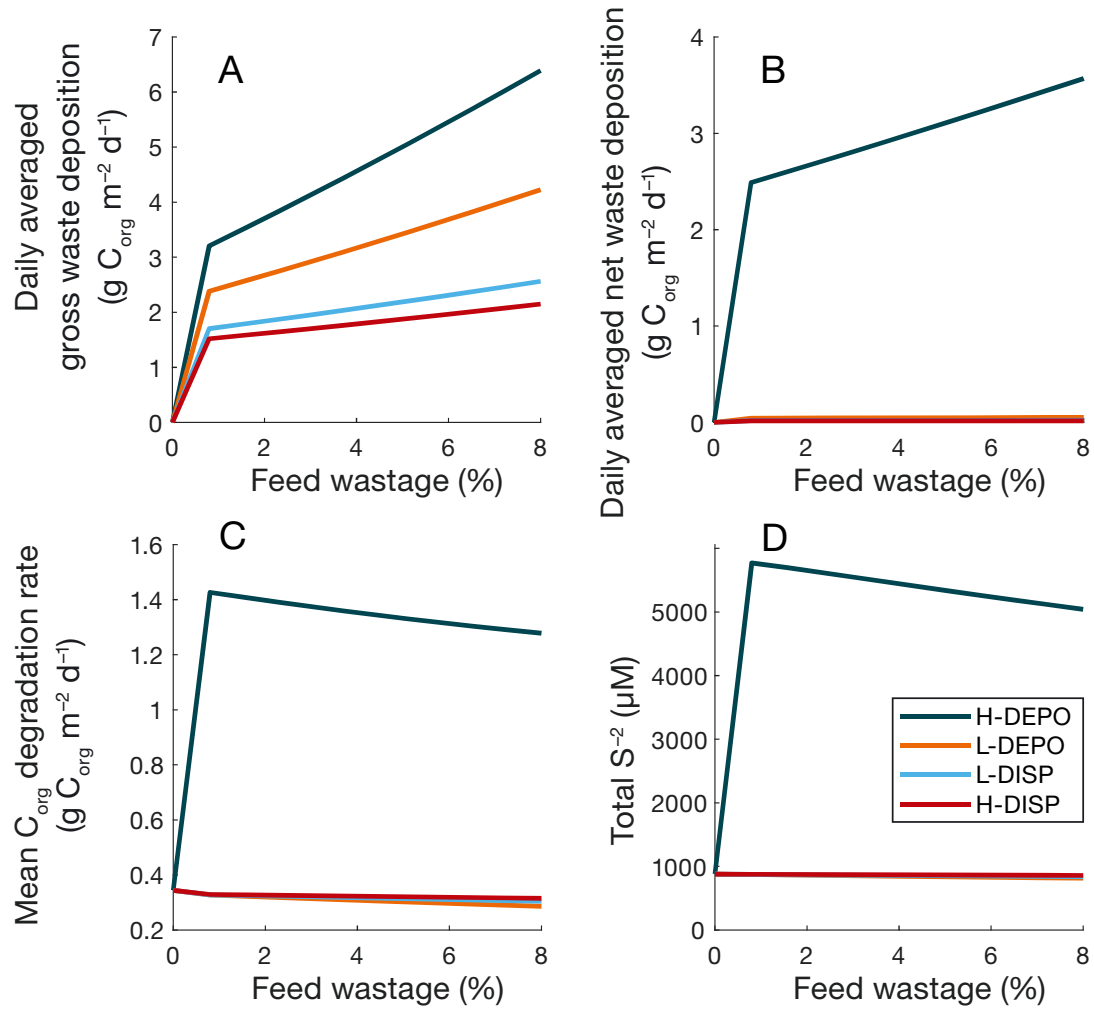

Fig. 6. Prediction of benthic processes in fish farm sediments exposed for the first time to fish farm organic wastes according to parameters given in Table 1, and assuming a feed wastage between 0 and $8 \%$ (in increments of $0.8 \%$ ). Simulations assume twice-per-day feeding and a percent feed wastage between zero (ambient deposition) and 8\%. The coloured lines represents different hydrodynamic scenarios: high and low deposition (H- and L-DEPO) and low and high dispersion (L- and H-DISP). (A) Daily averaged gross waste deposition. (B) Daily averaged net waste deposition. (C) Mean total $\mathrm{C}_{\text {org }}$ degradation of ambient particulate organic carbon and fish farm wastes. (D) Maximum total $\mathrm{S}^{2-}$ concentration predicted throughout the fish farm cycle. The break observed between $0 \%$ feed wastage and increasing values is caused by the transition from ambient deposition to farm deposition

$\left(8 \mathrm{~kg} \mathrm{~m}^{-3}\right)$ and digestive coefficients $(80 \%)$, among other fish farm parameters in Table 1, were constant in all simulations, so variations in these parameters may significantly affect predicted production and deposition of organic wastes.

Fig. $6 \mathrm{C}$ shows the mean $\mathrm{C}_{\text {org }}$ degradation rate calculated as a function of the percent feed wastage (for H-DEPO to $\mathrm{H}$-DISP). Maximum predicted $\mathrm{C}_{\text {org }}$ degradation rate in H-DEPO was $1.4 \mathrm{~g}$ $\mathrm{C} \mathrm{m}^{-2} \mathrm{~d}^{-1}$ (Fig. 6C), which became limited by oxidant supply $\left(\mathrm{O}_{2}, \mathrm{SO}_{4}{ }^{2-}\right)$ at any \% feed wastage greater than $0.8 \%$. Oxic respiration in fish farm sediments was lower than $10 \%$ in all hydrodynamic scenarios.

During fish culture, the nondispersive scenarios showed significant increases in total $\mathrm{S}^{2-}$ (Fig. 6D), up to $\sim 5800 \mu \mathrm{M}$ in $\mathrm{H}$-DEPO. This value is considered within the range of hypoxic to anoxic conditions according to Hargrave et al. (2008). At this level of sulfide accumulation, severe effects on sediment macroinfauna are expected in sediments. No increases above the ambient condition were predicted in sulfide concentration in the remaining hydrodynamic scenarios (Table 4).

As observed in Fig. 6C, a slight decrease in $\mathrm{C}_{\text {org }}$ degradation rates was predicted in the L-DEPO scenario with increases in waste deposition (represented here by the percent feed wastage). Likewise, the maximum predicted sulfide concentration in surface sediments (upper $2 \mathrm{~cm}$ ) followed a similar pattern, decreasing from $\sim 5800 \mu \mathrm{M}$ when exposed to the lowest $\%$ feed wastage tested in the model $(0.8 \%)$ to

Table 5. Assimilative capacity of organic wastes that prevent sulfide concentration $>1500 \mu \mathrm{M}$ in surface sediments (upper $2 \mathrm{~cm})\left(\mathrm{AC}-\mathrm{H}_{2} \mathrm{~S}\right)$. Degradation efficiency represents how much is predicted to be locally degraded in sediments in relation to gross waste deposition, the remaining fraction being resuspended, buried or accumulated in sediments by the end of the fish farm cycle. H-DEPO and L-DEPO: high and low deposition; L-DISP and H-DISP: low and high dispersion. NL: no limit based on $\mathrm{AC}-\mathrm{H}_{2} \mathrm{~S}$

\begin{tabular}{|c|c|c|c|c|}
\hline & H-DEPO & L-DEPO & L-DISP & H-DISP \\
\hline Gross assimilative capacity, $\mathrm{AC}-\mathrm{H}_{2} \mathrm{~S}\left(\mathrm{~g} \mathrm{C}_{\text {org }} \mathrm{m}^{-2} \mathrm{~d}^{-1}\right)$ & $0.6 \pm 0.3$ & $22.1 \pm 2.4$ & $81.0 \pm 2.8$ & $100.1 \pm 2.7$ \\
\hline Net deposition of organic wastes at $\mathrm{AC}-\mathrm{H}_{2} \mathrm{~S}\left(\mathrm{~g} \mathrm{C}_{\mathrm{org}} \mathrm{m}^{-2} \mathrm{~d}^{-1}\right)$ & 0.2 & 0.2 & 0.2 & 0.2 \\
\hline Ambient deposition $\left(\mathrm{g} \mathrm{C}_{\mathrm{org}} \mathrm{m}^{-2} \mathrm{~d}^{-1}\right)$ & 0.42 & 0.42 & 0.42 & 0.42 \\
\hline Total $\mathrm{C}_{\text {org }}$ degradation at $\mathrm{AC}-\mathrm{H}_{2} \mathrm{~S}\left(\mathrm{~g} \mathrm{C}_{\mathrm{org}} \mathrm{m}^{-2} \mathrm{~d}^{-1}\right)$ & 0.55 & 0.55 & 0.55 & 0.55 \\
\hline Degradation efficiency at $\mathrm{AC}-\mathrm{H}_{2} \mathrm{~S}(\%)$ & 41.0 & 0.9 & 0.3 & 0.2 \\
\hline Waste contribution to $\mathrm{C}_{\text {org }}$ degradation at $\mathrm{AC}-\mathrm{H}_{2} \mathrm{~S}(\%)$ & 37.2 & 37.7 & 37.5 & 37.5 \\
\hline Culture density at $\mathrm{AC}-\mathrm{H}_{2} \mathrm{~S}\left(\mathrm{~kg} \mathrm{~m}^{-3}\right)$ & $<3.2$ & $<4.6$ & NL & NL \\
\hline Average dispersion coefficient $(0-1)$ & 0.78 & 0.84 & 0.90 & 0.91 \\
\hline
\end{tabular}


$\sim 5050 \mu \mathrm{M}$ when exposed to an $8 \%$ feed wastage (Fig. 6D). This pattern was caused by the different approaches (i.e. formulas) used in the model to simulate $\mathrm{C}_{\text {org }}$ degradation rates (based on MichaelisMenten kinetics, R2, Table S2) and sulfide reoxidation (first-order reaction linearly dependent on sulfide and oxygen concentration, R8, Table S2). The difference in model formulation results in relatively higher reoxidation rates of sulfide with $\mathrm{O}_{2}$ compared to the $\mathrm{C}_{\text {org }}$ degradation rates when exposed to increasing levels of organic waste deposition.

Most of the produced sulfide under ambient conditions (non-farm) was reoxidized to $\mathrm{SO}_{4}{ }^{2-}$ (R5, Table 2), while precipitation to elemental sulfur (R7, Table 2) and to FeS (R8, Table 2) was negligible. In sediments exposed to organic farm wastes, the prediction shows that most of the sulfide was reoxidized with $\mathrm{O}_{2}$ or diffused out of sediments under anoxic conditions. In fish farm sediments, $\mathrm{Fe}^{2+}$ accumulated to concentrations up to $11.6 \mu \mathrm{M}$ (H-DEPO, $8 \%$ feed wastage). FeS precipitation increased significantly with increases in organic waste deposition due to the accumulation of reduced by-products $\left(\mathrm{Fe}^{2+}\right.$ and total $\mathrm{S}^{2-}$ ). Escape of dissolved $\mathrm{Fe}^{2+}$ to bottom waters was also predicted in anoxic conditions due to low reoxidation rates.

\section{Constrained optimizations}

Our estimates of the assimilative capacity of fish farm organic wastes through constrained optimizations, expressed as assimilable gross deposition, are site-specific, and dependent on hydrodynamics, background (ambient) deposition, bioturbation, and microbial activity. Except for porosity, these variables are time-dependent in the model. As mentioned above, assimilative capacity $\left(\mathrm{AC}-\mathrm{H}_{2} \mathrm{~S}\right)$ was defined as the gross $\mathrm{C}_{\text {org }}$ deposition rate that prevented sulfide concentration above $1500 \mu \mathrm{M}$ in surface sediments (upper $2 \mathrm{~cm})$. AC- $\mathrm{H}_{2} \mathrm{~S}$ increased from $0.6 \pm 0.3 \mathrm{~g} \mathrm{C}_{\text {org }} \mathrm{m}^{-2} \mathrm{~d}^{-1}$ in H-DEPO to $100.1 \pm 2.7 \mathrm{~g} \mathrm{C}_{\text {org }} \mathrm{m}^{-2} \mathrm{~d}^{-1}$ in H-DISP (Table 5). The high assimilative capacity in H-DISP is due to significant dispersion of organic wastes predicted in this scenario. As observed in Table 5, the degradation efficiency at AC- $\mathrm{H}_{2} \mathrm{~S}$ decreased considerably from $41 \%$ in H-DEPO to $0.2 \%$ in H-DISP. The decrease in degradation efficiency toward H-DISP was mostly due to increased erosion of wastes.

Net deposition represents the specific amount of organic material that remains in sediments after erosion, and therefore that is susceptible to degradation. The net deposition of organic wastes at $\mathrm{AC}-\mathrm{H}_{2} \mathrm{~S}$ was predicted to be equal to $0.2 \mathrm{~g} \mathrm{C}_{\text {org }} \mathrm{m}^{-2} \mathrm{~d}^{-1}$ and did not differ between hydrodynamic scenarios as sediment properties were the same, particularly porosity. This amount represents the amount of organic carbon that can be degraded on top of ambient deposition without exceeding $\mathrm{AC}-\mathrm{H}_{2} \mathrm{~S}$.

Maximum wastage rates and culture densities

According to model predictions, the maximum wastage rate assuming an $8 \%$ feed wastage was equal to $27.4 \mathrm{~g} \mathrm{C} \mathrm{m}^{-2} \mathrm{~d}^{-1}$; however, it increased at higher culture densities (e.g. $\sim 59 \mathrm{~g} \mathrm{C} \mathrm{m}^{-2} \mathrm{~d}^{-1}$ at $17 \mathrm{~kg}$ $\mathrm{m}^{-3}$ ). The predicted wastage rates at $\mathrm{AC}-\mathrm{H}_{2} \mathrm{~S}$ are equal to $2.3,148.4,803.2 \mathrm{~g} \mathrm{C}_{\text {org }} \mathrm{m}^{-2} \mathrm{~d}^{-1}$ for H-DEPO, L-DEPO, and L-DISP, respectively. These values were calculated based on average dispersion coefficients (Table 5) estimated for each scenario (i.e. the average fraction of produced wastes deposited out of the fish cage bottom area). Assuming a feed wastage of $3 \%$, fish may be cultured in H-DEPO without exceeding AC- $\mathrm{H}_{2} \mathrm{~S}$ at culture densities as high as $3.2 \mathrm{~kg} \mathrm{~m}^{-3}$ (not commercially viable). In contrast, and according to model predictions, fish production in L-DEPO to $\mathrm{H}$-DISP is not limited by $\mathrm{AC}-\mathrm{H}_{2} \mathrm{~S}$.

A traffic-light model of the local environmental sustainability of fish farm operations was developed based on scenario simulations and benthic response to organic enrichment (Fig. 7). The precautionary area (yellow) that separates sustainable (green) from unsustainable (red) aquaculture practices was established whenever a specific combination of wastage rate and hydrodynamic conditions led to sulfide concentration in surface sediments (upper $2 \mathrm{~cm}$ ) between 1500 and $3000 \mu \mathrm{M}$ (Fig. 7). As expected, the area defining sustainable aquaculture practices (shown in green) decreased considerably with increased percent wastage rate, as well as toward the more depositional environments. As indicated above, H-DEPO provides less suitable conditions for fish farming, even at low culture density. In contrast, the DISP scenarios are those that present lower local accumulation of organic wastes.

\section{DISCUSSION}

\section{Model performance and prediction}

Although the simulations of transient sediment fluxes may be improved by a better representation of physical forcing (e.g. wave-driven porewater ex- 


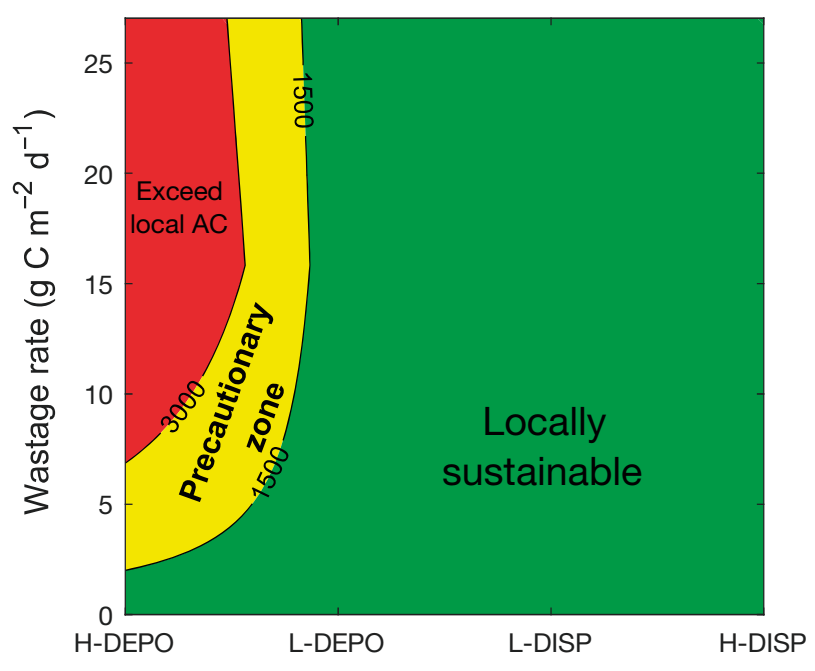

Fig. 7. Traffic-light model predicting environmental sustainability of aquaculture operations based on hydrodynamic conditions, the wastage rate at the base of the fish cage, and the predicted benthic response to organic enrichment. Environmental performance of aquaculture operations is considered successful if assimilative capacity $\left(\mathrm{AC}-\mathrm{H}_{2} \mathrm{~S}\right)$ is not exceeded throughout the fish farm cycle. The precautionary area (yellow) that separates sustainable (green) from unsustainable (red) aquaculture is defined based on the maximum sulfide concentration predicted in surface sediments (upper $2 \mathrm{~cm}$ ) throughout the fish farm cycle. The precautionary limits are 1500 to $3000 \mu \mathrm{M}$ total $\mathrm{S}^{2-}$. The traffic-light model was developed considering twice-per-day feeding (20 min each), constant production of feces, a constant culture density of $8 \mathrm{~kg} \mathrm{~m}^{-3}$, and a wastage rate between 0 (ambient deposition) and $27.4 \mathrm{~g} \mathrm{C}_{\text {org }} \mathrm{m}^{-2} \mathrm{~d}^{-1}$ ( 0 to $8 \%$ feed wastage)

change), geochemical (e.g. different $\mathrm{C}_{\text {org }}$ pools), and biological processes (e.g. sediment irrigation), simple numerical models, such as the one presented here, provide a cost-effective approach to study the behaviour of sediments exposed to organic enrichment. Its simplicity relative to more sophisticated reactiontransport models facilitates the exploration of multiple scenarios (hydrodynamics, oxidant availability in bottom water, waste production, etc.), and, more importantly, allows us to explore the effects of the sustained accumulation of organic matter and metabolic by-products on assimilative capacity.

The introduction of an explicit formulation for microbial activity, based on Talin et al. (2003), allowed us to speculate on the impact of microbial dynamics on $\mathrm{C}_{\text {org }}$ degradation. Future considerations may consider the impact of chemotherapeutic (e.g. antibiotics) on microbial activity, and of stochastic events (short-term hypoxia, storms) on $\mathrm{C}_{\text {org }}$ degradation rates.

The incorporation of optimization techniques as a complement to more traditional scenario analysis allows the prediction of sediment assimilative capac- ity based on predefined environmental goals. Constrained optimizations were carried out by gradually increasing gross $\mathrm{C}_{\text {org }}$ deposition rates until assimilative capacity was reached. At assimilative capacity, all biological (bioturbation and microbial activity) and geochemical (concentration of $\mathrm{C}_{\text {org, }}$ oxidants, and reduced by-products) variables reach equilibrium in sediments. This steady-state condition is hardly met in real farm operations since sediments are usually exposed to highly variable organic deposition rates. This situation may increase the chance of an early transition to suboxic conditions depending on the response time of macrofaunal and microbial communities to the changes in organic deposition. Despite the assumption of steady-state conditions, model results showed close agreement between constrained optimizations and scenario analysis. This fact highlights the potential role that other factors, beyond benthic adaptation, play on the sediment assimilative capacity (e.g. bottom oxidant renewal).

Also relevant for model predictions was the incorporation of husbandry practices at the fish farm. The model is forced by wastage rates and associated parameters (culture density, digestive coefficients, and feeding strategy). This allowed us to link benthic processes to the fish farm operation, an aspect missing in most approaches of environmental impact assessment of organic enrichment. A recent exception to this is provided by Brigolin et al. (2014).

The model uses analytical forcing (tidal current, waste deposition), and is not explicitly ground-truthed, although an assessment of model performance is provided by comparing fluxes, rates, and state variables $\left(\mathrm{C}_{\text {org }}\right.$ and $\mathrm{H}_{2} \mathrm{~S}$ ) with observations. Based on sediment trap data (Abo \& Yokoyama 2007, Brigolin et al. 2009) and model predictions (Chang et al. 2014), waste deposition rates to the seafloor may reach values as high as $25.4 \mathrm{~g} \mathrm{C}_{\text {org }} \mathrm{m}^{-2} \mathrm{~d}^{-1}$ under current fish farm practices. The model predicts waste deposition rates (total daily gross values) to sediments underlying the fish cage as high as $6.4 \mathrm{~g} \mathrm{C}_{\text {org }} \mathrm{m}^{-2} \mathrm{~d}^{-1}$ in the worstcase scenario considered in simulations (H-DEPO, $8 \%$ feed wastage). Despite the predicted accumulation of waste, H-DEPO does not represent the worst feasible scenario that can be produced by the model, as only $\sim 22 \%$ of produced wastes were predicted to reach sediments immediately below the fish cage, the rest dispersed in the water column. A higher deposition may be predicted at lower depth or lower mean current speed.

Reported TOU for fish farm sediments reach up to $\sim 100 \mathrm{mmol} \mathrm{m}^{-2} \mathrm{~d}^{-1}$ (Findlay \& Watling 1997, Hargrave et al. 1997). The TOU predictions for the high- 
deposition scenario (H-DEPO, 3\% feed wastage; Fig. 2B) averaged $10.7 \mathrm{mmol} \mathrm{m}^{-2} \mathrm{~d}^{-1}$ for the entire cycle, with a maximum of $15.8 \mathrm{mmol} \mathrm{m}^{-2} \mathrm{~d}^{-1}$. These values are close to the average observed in similar fish farm cohesive sediments in southern Nova Scotia, which averaged $13.5 \pm 8.2 \mathrm{mmol} \mathrm{m}^{-2} \mathrm{~d}^{-1}(\mathrm{n}=55$, maximum $40.8 \mathrm{mmol} \mathrm{m}^{-2} \mathrm{~d}^{-1}$ ).

Similarly, maximum $\mathrm{C}_{\text {org }}$ concentration predicted in the simulations $(2.6 \%$ dry weight, H-DEPO, $3 \%$ feed wastage; Fig. 2A) was within the range reported for organically enriched sediments, which may reach up to $\sim 10 \%$ in heavily loaded conditions (pellet layer) (Hargrave et al. 1995). Nonetheless, further data, particularly regarding hydrodynamic and gross deposition under the cages, are required for a direct comparison of scenario simulations and observations.

Our model predicts H-DEPO sulfide concentrations of $\sim 6000 \mu \mathrm{M}$ by the end of the fish farm cycle ( $3 \%$ feed wastage). Although observations by Hargrave et al. (1995) have shown sulfide concentrations $>3000 \mu \mathrm{M}$ at $\mathrm{C}_{\text {org }}$ concentrations as low as $1 \%$, this is not necessarily the dominant pattern observed in organically enriched sediments. The high predicted sulfide concentration compared to the relatively low $\mathrm{C}_{\text {org }}$ concentration suggests that the model might be overestimating sulfide concentration in surface sediments. Further adjustment of model parameters, particularly those related to solid burial $\left(w_{\text {sed }}\right)$ and reoxidation of sulfide $\left(k_{\text {Total }} \mathrm{S}_{\mathrm{SL}, 0 x 1}^{2-}\right)$, are required to better reproduce dominant patterns observed at aquaculture sites.

\section{Sediment assimilative capacity}

Only a few estimates of sediment assimilative capacity have been reported in the literature. $\mathrm{C}_{\text {org }}$ loading rates causing marked anoxic conditions vary by an order of magnitude, from 0.36 to $11.4 \mathrm{~g} \mathrm{C}_{\text {org }}$ $\mathrm{m}^{-2} \mathrm{~d}^{-1}$ (Cranston 1994, Hargrave 1994, Findlay \& Watling 1997, Fisheries and Oceans Canada 2004, Chamberlain \& Stucchi 2007, Environment Canada 2009, Chang et al. 2012). Based on empirical observations, Findlay \& Watling (1997) suggested that sedimentation rates in excess of 2.4-4.8 $\mathrm{g} \mathrm{C}_{\text {org }} \mathrm{m}^{-2} \mathrm{~d}^{-1}$ (200-400 $\left.\mathrm{mmol} \mathrm{C} \mathrm{m}^{-2} \mathrm{~d}^{-1}\right)$ in areas exposed to bottom currents of $<10 \mathrm{~cm} \mathrm{~s}^{-1}$ may lead to anoxic conditions and formation of sulfur bacteria mats. Likewise, the Department of Environment of New Brunswick, Canada, has indicated that sulfide concentrations $>3000 \mu \mathrm{M}$ and $\mathrm{C}_{\text {org }}$ deposition rates $>2 \mathrm{~g} \mathrm{C}_{\text {org }} \mathrm{m}^{-2} \mathrm{~d}^{-1}$ are the threshold levels at which adverse environmental effects are expected in sediments (NBDENV 2012). These values agree with the site-specific max- imum loading rates (gross values) predicted by the model, which range between 0.6 and $22.1 \mathrm{~g} \mathrm{C}_{\text {org }} \mathrm{m}^{-2}$ $\mathrm{d}^{-1}$ in poorly flushed environments ( $\mathrm{H}$ - and L-DEPO). According to simulations, $\mathrm{AC}-\mathrm{H}_{2} \mathrm{~S}$ does not limit farm production in environments exposed to mean tidal currents $>9.5 \mathrm{~cm} \mathrm{~s}^{-1}$ (DISP scenarios), where most fish farm organic wastes are dispersed to the far-field or resuspended after deposition.

In addition, model results suggest that ambient sediments initially exposed to organic wastes possess a higher assimilative capacity than sediments with an exposure history. The latter condition occurs when the oxidants have been partially or fully depleted, or when refractory organic wastes remain in sediments. This chronology, already emphasized in the literature (McGhie et al. 2000), needs to be considered in management strategies of finfish aquaculture sites, as it affects the transition to suboxic conditions and the recovery time of fallowed sediments.

Assimilative capacity of sediments to degrade organic wastes is expected to increase in well-flushed environments due to the increased renewal of oxidants in bottom waters. In contrast, net $\mathrm{C}_{\text {org }}$ deposition is expected to decrease as flushing increases. As a result, benthic metabolism may be primarily defined by the balance between oxidant availability and net $\mathrm{C}_{\text {org }}$ deposition (deposition - erosion). Nonetheless, several additional factors add complexity to this relationship. First, animal-sediment relationships may play a major role in oxidant availability and $\mathrm{C}_{\text {org }}$ degradation rates in sediments. Two variables are emphasized in this model: bioturbation and microbial activity. Sediment-water exchange of solutes is partially controlled by bioturbating activity, which in nature maximizes at intermediate $\mathrm{C}_{\text {org }}$ loading rates and low concentration of reduced compounds such as sulfide. Only the effects of increased toxic sulfide concentration were incorporated in the model, not the effects of increased carbon availability, which should be included in future model developments. In contrast, microbial activity was represented explicitly, assuming growth rates directly proportional to $\mathrm{C}_{\text {org }}$ degradation rates (combined aerobic and anaerobic). This factor is not usually considered in diagenetic models, where $\mathrm{C}_{\text {org }}$ degradation is modelled as a function of oxidant availability and maximum degradation rates. According to model simulations, $\mathrm{C}_{\text {org }}$ degradation efficiency increases with exposure time to organic wastes as a result of sustained increases in microbial activity. However, this prediction needs to be contrasted with the loss of macrofaunal biomass/ activity observed under heavily loaded conditions, and their impact on $\mathrm{C}_{\text {org }}$ degradation rates. 
A second relevant aspect for modelling sediment $\mathrm{C}_{\text {org }}$ degradation is the accurate representation of transport mechanisms of solutes and particles across the sediment-water interface. Fish farms prefer sites with relatively high flushing rates to ensure adequate ventilation within cages, as well as to prevent excessive accumulation of organic wastes in beds underlying cages. The minimum current speed required for safe operation of fish farms varies according to fish size and fish density within cages (Page et al. 2005, Solstorm et al. 2015). Page et al. (2005) predicted that current speeds of $\sim 2 \mathrm{~cm} \mathrm{~s}^{-1}$ for 40 min might induce $\mathrm{O}_{2}$ depletion within fish cages stocked with pre-market salmon. This threshold varies with culture density but roughly indicates the lower current required for safe operation. On the other side, estimates of critical current speed causing fatigue in small and large postsmolts and adults range between 80.6 and $99.5 \mathrm{~cm} \mathrm{~s}^{-1}$ (Remen et al. 2016). Within this range of current speed, sediment type may vary from cohesive muds to permeable sands, and, consequently, the dominant transport mechanisms within sediments. In sandy beds with permeabilities greater than $10^{-12} \mathrm{~m}^{2}$, advection may play a significant role in the transport of solutes across the sediment-water interface (Huettel et al. 1998). Likewise, flow- and topography-induced advective fluxes can be enhanced by 50 times relative to molecular diffusion (Huettel et al. 2003), and reach tens of centimetres within permeable sediments (Santos et al. 2012). This may significantly influence the capacity of sediments to degrade organic matter, particularly of dissolved compounds. Differences in porosity and permeability were not included in the model, nor were porewater flows associated with tidal pumping, flow- or topography-induced pressure gradients (Santos et al. 2012). Accounting for the differences in surface and in-bed transport is important to improve modelled $\mathrm{C}_{\text {org }}$ degradation at fish farm sediments.

\section{Concepts and models}

Our model demonstrates that the balance of culture density, waste production, and hydrodynamics can be used to simulate benthic metabolic responses to fish farm organic enrichment. Moreover, the model is used to formalize the definition of assimilative capacity in terms of a deposition rate (gross and net) that maintains predefined environmental quality criteria. We suggest that the model has significant applications to the regulatory environment, and fills a void in predicting benthic impacts of aquaculture, as well as in the planning of new farm sites.
The concept of sediment assimilative capacity was initially adopted from Omori et al. (1994, p. 73), who define it as 'the capacity for oxygenic degradation [oxic respiration] of organic matter at the bottom of the system'. In their conceptual model, oxic respiration is assumed to peak at some intermediate organic carbon loading rate, the higher extreme dominated by anaerobic degradation. This peak and corresponding sulfide concentration represents the upper limit of oxic assimilative capacity, and of sustainable organic loading at fish farm sites. We build on this work and extend it to consider alternative sustainability criteria and some weaknesses associated with this definition and the modelling approach. The underlying assumption of steady state in Omori's work implies no accumulation of organic material over time, the opposite case of sediments exposed to aquaculture wastes, especially in poorly flushed conditions. This assumption limits the capacity of the model to predict the temporal evolution of metabolic conditions in organically enriched sediments. Second, the occurrence of time lags in sulfide accumulation in relation to $\mathrm{C}_{\text {org }}$ deposition may prevent its utilization as an indicator of assimilative capacity as proposed by Omori et al. (1994). The immediate accumulation of sulfide may not necessarily be expected in all sedimentary environments exposed to organic enrichment. A lagged increase in sediment sulfide may occur if oxygen supply is greater than oxygen demand in the initial stages of organic loading. This was not observed in the simulations, as they represent diffusion-dominated environments (muddy sediments), but it may be expected in permeable sediments subject to porewater advection, and therefore higher $\mathrm{O}_{2}$ renewal. Evidence of time lags in ambient sediments has been documented by Luff \& Moll (2004) and suggested as well by Chang et al. (2012).

We chose a transient approach to simulate $\mathrm{C}_{\text {org }}$ diagenesis below fish farm cages. Instead of determining $\mathrm{C}_{\text {org }}$ deposition at the point of maximum oxic respiration, we used diagenetic modelling to estimate the $\mathrm{C}_{\text {org }}$ deposition rate that maximizes total $\mathrm{C}_{\text {org }}$ degradation while preventing sulfide concentration $>1500 \mu \mathrm{M}\left(\mathrm{AC}-\mathrm{H}_{2} \mathrm{~S}\right)$. This approach allows us to consider the effects of $\mathrm{C}_{\text {org }}$ accumulation and the background deposition over which organic enrichment occurs. This is critical in that the history of $\mathrm{C}_{\text {org }}$ degradation and trophic condition (from oligotrophic to eutrophic) control the capacity of the benthos to deal with excess organic loading. Assimilative capacity is thus recognized as a finite and timeand space-dependent environmental threshold that may increase or decrease according to the history of 
$\mathrm{C}_{\text {org }}$ degradation, benthic composition, and sediment type.

We emphasize that $\mathrm{C}_{\text {org }}$ degradation rates predicted in the simulations are largely dominated by anaerobic degradation, even in sediments exposed to ambient deposition. This is due to the vertical extent covered by the model $(50 \mathrm{~cm})$, which includes a large anoxic zone, as well as because sediments simulated here are of the muddy type, that is to say diffusiondominated. In this case, as opposed to permeable sands, oxic respiration is largely restricted to the upper millimetres of sediments.

\section{Application to regulation}

Successful environmental management of marine fish farms requires assurance that production levels are within an area's capacity. This also implies the maintenance of ecosystem function and state within desired limits, despite uncertainties in management systems and/or environmental conditions. The advancement of knowledge regarding sustainable limits of organic loading can promote the implementation of anticipatory rather than reactive management practices, decreasing the risk of self-pollution of aquaculture grounds. The combination of geochemical analysis and diagenetic modelling provides a valuable tool to accomplish this objective.

Monitoring of benthic health has been based on biological and geochemical parameters. Their integration has led to the development of multiple benthic condition indices (Rhoads \& Germano 1982, Findlay \& Watling 1997, Nilsson \& Rosenberg 1997, Fossing et al. 2004, Hargrave et al. 2008, Borja et al. 2009, Wilson \& Vopel 2012, Simone \& Grant 2017). Several studies have suggested that recovery of macrofaunal communities from eutrophicated conditions under salmon farms requires considerably more time than chemical recovery (Chang \& Page 2011 and references therein), making biological indicators a better indicator of recovery. However, a drawback of macrofaunal analysis is that it requires considerably more analysis time and expertise on the composition of local benthic communities (Wildish et al. 2001). In contrast, geochemical indicators such as sediment sulfide, redox potential (Eh), and $\mathrm{C}_{\text {org }}$ are widely applicable to any sedimentary environment, their response to organic enrichment is well understood, and cost-effective methods are available for routine analysis.

Sulfide is considered one of the major regulatory variables in Canada and elsewhere, yet models predicting sediment concentration are sorely lacking.
Modelling capability for these benthic variables and oxic state adds powerful capability to the regulatory regime. When linked to dispersion models and fish growth models, they can be used to predict fish biomass that relates to any given sulfide concentration in a particular sedimentary environment.

In this context, diagenetic models can serve as effective tools to predict: (1) values of environmental regulatory variables such as sulfide concentration, (2) the transition to suboxic conditions, (3) sustainable $\mathrm{C}_{\text {org }}$ loading, and (4) recovery rates of organically enriched sediments. Applications cover the entire fish farm production cycle, including the a priori assessment of new aquaculture sites (e.g. license or lease applications), throughout operations (e.g. farm management plans, fallowing), and after complete cessation of aquaculture operations (e.g. site remediation plans).

\section{Application to an ecosystem approach to aquaculture}

Our model has demonstrated its application to nonaquaculture conditions in the 'ambient' scenarios. This outcome means that the model capability can be extended to the far-field. The present model is onedimensional but is readily extended to 2 or 3 dimensions when coupled with a circulation model. Its incorporation in spatially explicit simulations is expected to facilitate the development of spatial planning tools and the incorporation of an ecosystem-oriented approach to salmon aquaculture (Soto et al. 2011, Filgueira et al. 2014). This is particularly relevant for areas of rapid expansion of salmon aquaculture such as Nova Scotia (Canada) and Southern Chile. Applications include aquaculture siting optimization and the evaluation of interactions of finfish aquaculture with other human activities, ecosystem services, and sensitive biological communities (e.g. shellfish aquaculture, $\mathrm{C}$ and nutrient cycling, nursery grounds). It is important to recognize that in a spatial mode, the model allows assessment of the distribution of sulfides, sediment carbon, etc. This spatial component allows scaling of potential impacts, and thus their interpretation in an appropriate context beyond merely local near-field effects.

Acknowledgements. This study was supported by funds to J.G. as the NSERC-Cooke Industrial Research Chair in Sustainable Aquaculture, and to F.B. by the scholarship program BECAS CHILE for doctoral studies. We thank Ramon Filgueira, Bernard Boudreau, Chris Algar, Michelle Simone, Kevin Sorochan, and Martin Bravo for their support and valuable suggestions. 


\section{LITERATURE CITED}

Abo K, Yokoyama H (2007) Assimilative capacity of fish farm environments as determined by the benthic oxygen uptake rate: studies using a numerical model. Bull Fish Res Agency Japan 19:79-87

Borja Á, Rodríguez JG, Black K, Bodoy A and others (2009) Assessing the suitability of a range of benthic indices in the evaluation of environmental impact of fin and shellfish aquaculture located in sites across Europe. Aquaculture 293:231-240

Boudreau BP (1996) A method-of-lines code for carbon and nutrient diagenesis in aquatic sediments. Comput Geosci 22:479-496

Brigolin D, Pastres R, Nickell TD, Cromey CJ, Aguilera DR, Regnier P (2009) Modelling the impact of aquaculture on early diagenetic processes in sea loch sediments. Mar Ecol Prog Ser 388:63-80

Brigolin D, Meccia VL, Venier C, Tomassetti P, Porrello S, Pastres R (2014) Modelling biogeochemical fluxes across a Mediterranean fish cage farm. Aquacult Environ Interact 5:71-88

Brooks KM (2001) An evaluation of the relationship between salmon farm biomass, organic inputs to sediments, physicochemical changes associated with those inputs and the infaunal response - with emphasis on total sediment sulfides, total volatile solids, and oxidation reduction potential as surrogate endpoints for biological monitoring. Final Report. Aquatic Environmental Sciences, Port Townsend, WA

Brooks KM, Mahnken CV (2003) Interactions of Atlantic salmon in the Pacific Northwest environment: II. Organic wastes. Fish Res 62:255-293

Burt W, Thomas H, Fennel K, Horne E (2013) Sedimentwater column fluxes of carbon, oxygen and nutrients in Bedford Basin, Nova Scotia, inferred from ${ }^{224}$ Ra measurements. Biogeosciences 10:53-66

Buschmann $\mathrm{AH}$, Riquelme VA, Hernández-González MC, Varela D and others (2006) A review of the impacts of salmonid farming on marine coastal ecosystems in the southeast Pacific. ICES J Mar Sci 63:1338-1345

Chamberlain J, Stucchi D (2007) Simulating the effects of parameter uncertainty on waste model predictions of marine finfish aquaculture. Aquaculture 272:296-311

Chang B, Page F (2011) Analysis of results from the Environmental Management Program Tier 1 monitoring of salmon farms in southwestern New Brunswick, Bay of Fundy: relationships between sediment sulfide concentration and selected parameters, 2002-2008. Can Tech Rep Fish Aquat Sci 2936

Chang B, Page F, Losier R, McCurdy E (2012) Predicting organic enrichment under marine finfish farms in southwestern New Brunswick, Bay of Fundy: comparisons of model predictions with results from spatially-intensive sediment sulfide sampling. DFO Can Sci Advis Sec Res Doc 2012/078

Chang BD, Page FH, Losier RJ, McCurdy EP (2014) Organic enrichment at salmon farms in the Bay of Fundy, Canada: DEPOMOD predictions versus observed sediment sulfide concentrations. Aquacult Environ Interact 5:185-208

* Chapelle A, Ménesguen A, Deslous-Paoli JM, Souchu P, Mazouni N, Vaquer A, Millet B (2000) Modelling nitrogen, primary production and oxygen in a Mediterranean lagoon. Impact of oysters farming and inputs from the watershed. Ecol Modell 127:161-181
Cranston R (1994) Dissolved ammonium and sulfate gradients in surficial sediment pore water as a measure of organic carbon burial rate. Can Tech Rep Fish Aquat Sci 1949:93-120

Cromey C, Black K, Edwards A, Jack I (1998) Modelling the deposition and biological effects of organic carbon from marine sewage discharges. Estuar Coast Shelf Sci 47: 295-308

Cromey CJ, Nickell TD, Black KD (2002a) DEPOMODmodelling the deposition and biological effects of waste solids from marine cage farms. Aquaculture 214:211-239

* Cromey C, Nickell T, Black K, Provost P, Griffiths C (2002b) Validation of a fish farm waste resuspension model by use of a particulate tracer discharged from a point source in a coastal environment. Estuaries 25:916-929

De Gaetano P, Doglioli AM, Magaldi MG, Vassallo P, Fabiano $M$ (2008) FOAM, a new simple benthic degradative module for the LAMP3D model: an application to a Mediterranean fish farm. Aquacult Res 39:1229-1242

Environment Canada (2009) Organic waste and feed deposits on bottom sediments from aquaculture operations: scientific assessment and guidance. Ecosystem health: science-based solutions report no. 1-14. National Guidelines and Standards Office, Environment Canada, Ottawa

*Eyre BD, Ferguson AJ (2009) Denitrification efficiency for defining critical loads of carbon in shallow coastal ecosystems. Hydrobiologia 629:137-146

* Filgueira R, Grant J, Strand O (2014) Implementation of marine spatial planning in shellfish aquaculture management: modeling studies in a Norwegian fjord. Ecol Appl 24:832-843

Findlay RH, Watling L (1997) Prediction of benthic impact for salmon net-pens based on the balance of benthic oxygen supply and demand. Mar Ecol Prog Ser 155:147-157

Fisheries and Oceans Canada (2015) Aquaculture monitoring standard. www.dfo-mpo.gc.ca/aquaculture/management-gestion/AAR_monitoring_standard_july_2015.pdf

Fossing H, Berg P, Thamdrup B, Rysgaard S, Sørensen HM, Nielsen K (2004) A model set-up for an oxygen and nutrient flux model for Aarhus Bay (Denmark). NERI Technical Report No. 483. Danish National Environmental Research Institute

Gillibrand P, Gubbins M, Greathead C, Davies I (2002) Scottish executive locational guidelines for fish farming: predicted levels of nutrient enhancement and benthic impact. Scottish Fisheries Research Report 63:52

Hammond DE, Fuller C (1979) The use of radon-222 to estimate benthic exchange and atmospheric exchange rates in San Francisco Bay. In: Conomos TJ (ed) San Francisco Bay: the urbanized estuary. Pacific Division of the American Association for the Advancement of Science, San Francisco, CA, p 213-230

Hargrave B (ed) (1994) Modeling benthic impacts of organic enrichment from marine aquaculture. Can Tech Rep Fish Aquat Sci 1949

Hargrave B (1995) Past and future studies with sediment traps in Canadian east coast waters. In: Floderus S, Heiskanen AS, Olesen M, Wassmann P (eds) Sediment trap studies in the Nordic countries. Nurmi Print Oy, Helsinki, p 10-27

Hargrave BT (2010) Empirical relationships describing benthic impacts of salmon aquaculture. Aquacult Environ Interact 1:33-46

Hargrave BT, Phillips G, Doucette L, White M, Milligan T, Wildish D, Cranston R (1995) Biogeochemical observa- 
tions to assess benthic impacts of organic enrichment from marine aquaculture in the Western Isles region of the Bay of Fundy, 1994. Can Tech Rep Fish Aquat Sci 1995

Hargrave BT, Holmer M, Newcombe CP (2008) Towards a classification of organic enrichment in marine sediments based on biogeochemical indicators. Mar Pollut Bull 56: 810-824

Hatcher A, Grant J, Schofield B (1994) Effects of suspended mussel culture (Mytilus spp.) on sedimentation, benthic respiration and sediment nutrient dynamics in a coastal bay. Mar Ecol Prog Ser 115:219-235

Hochard S, Pinazo C, Grenz C, Evans JLB, Pringault O (2010) Impact of microphytobenthos on the sediment biogeochemical cycles: a modeling approach. Ecol Modell 221:1687-1701

Holmer M, Wildish D, Hargrave B (2005) Organic enrichment from marine finfish aquaculture and effects on sediment biogeochemical processes. In: Hargrave BT (ed) Environmental effects of marine finfish aquaculture. Springer, Berlin, p 181-206

* Huettel M, Ziebis W, Forster S, Luther G (1998) Advective transport affecting metal and nutrient distributions and interfacial fluxes in permeable sediments. Geochim Cosmochim Acta 62:613-631

Huettel M, Røy H, Precht E, Ehrenhauss S (2003) Hydrodynamical impact on biogeochemical processes in aquatic sediments. In: Kronvang B (ed) The interactions between sediment and water. Proc 10th Int Symp. Kluwer Academic Press, London, p 231-236

Jørgensen SE, Bendoricchio G (2001) Fundamentals of ecological modelling. Elsevier, Amsterdam

Katsev S, Rancourt D, L'Heureux I (2004) dSED: a database tool for modeling sediment early diagenesis. Comput Geosci 30:959-967

Kaushik S (2013) Feed management and on-farm feeding practices of temperate fish with special reference to salmonids. In: Hasan MR, New MB (eds) On-farm feeding and feed management in aquaculture. FAO Fisheries and Aquaculture. Technical Paper No. 583. FAO, Rome, p 519-551

La Rosa T, Mirto S, Mazzola A, Danovaro R (2001) Differential responses of benthic microbes and meiofauna to fishfarm disturbance in coastal sediments. Environ Pollut 112:427-434

Luff R, Moll A (2004) Seasonal dynamics of the North Sea sediments using a three-dimensional coupled sedimentwater model system. Cont Shelf Res 24:1099-1127

Mazzola A, Mirto S, La Rosa T, Fabiano M, Danovaro R (2000) Fish-farming effects on benthic community structure in coastal sediments: analysis of meiofaunal recovery. ICES J Mar Sci 57:1454-1461

*McGhie TK, Crawford CM, Mitchell IM, O'Brien D (2000) The degradation of fish-cage waste in sediments during fallowing. Aquaculture 187:351-366

* Meyer-Reil LA, Köster M (2000) Eutrophication of marine waters: effects on benthic microbial communities. Mar Pollut Bull 41:255-263

Mulsow S, Krieger Y, Kennedy R (2006) Sediment profile imaging (SPI) and micro-electrode technologies in impact assessment studies: example from two fjords in Southern Chile used for fish farming. J Mar Syst 62: 152-163

NBDELG (New Brunswick Department of Environment and Local Government) (2012) Standard operating practices for the environmental monitoring of the marine finfish cage aquaculture industry in New Brunswick. NBDELG, Fredericton. www2.gnb.ca/content/dam/gnb/Departments/ env/pdf/MarineAquaculture-AquacoleMarin/Standard OperatingPracticeFinfish.pdf (accessed June 2018)

NBDENV (New Brunswick Department of Environment) (2012) Environmental management program for the marine finfish cage aquaculture industry in New Brunswick V3.0. NBDENV. www2.gnb.ca/cfontent/gnb/en/ services/services_renderer.520.Marine_Finfish_Aquacul ture_Approval.html (accessed June 2018)

*Nilsson H, Rosenberg R (1997) Benthic habitat quality assessment of an oxygen stressed fjord by surface and sediment profile images. J Mar Syst 11:249-264

Nilsson HC, Rosenberg R (2000) Succession in marine benthic habitats and fauna in response to oxygen deficiency: analysed by sediment profile-imaging and by grab samples. Mar Ecol Prog Ser 197:139-149

NSDFA (Nova Scotia Fisheries and Aquaculture) (2014) Standard operating procedures for the environmental monitoring of marine aquaculture in Nova Scotia. NSDFA, Halifax. http://0-fs01.cito.gov.ns.ca.legcat.gov. ns.ca/deposit/b10635841.pdf

* Omori K, Hirano T, Takeoka H (1994) The limitations to organic loading on a bottom of a coastal ecosystem. Mar Pollut Bull 28:73-80

Page F, Losier R, McCurdy P, Greenberg D, Chaffey J, Chang B (2005) Dissolved oxygen and salmon cage culture in the southwestern New Brunswick portion of the Bay of Fundy. In: Hargrave BT (ed) Environmental effects of marine finfish aquaculture. Springer, Berlin, p 1-28

Paraska DW, Hipsey MR, Salmon SU (2014) Sediment diagenesis models: review of approaches, challenges and opportunities. Environ Model Softw 61:297-325

Pearson T, Rosenberg R (1978) Macrobenthic succession in relation to organic enrichment and pollution of the marine environment. Oceanogr Mar Biol Annu Rev 16:229-311

Petersen S, Sutherland T, Higgs D (2005) Physical and chemical characterization of salmonid feed pellets. Can Data Rep Fish Aquat Sci 1159

Kemen M, Solstorm F, Bui S, Klebert P and others (2016) Critical swimming speed in groups of Atlantic salmon Salmo salar. Aquacult Environ Interact 8:659-664

* Rhoads DC, Germano JD (1982) Characterization of organism-sediment relations using sediment profile imaging: an efficient method of remote ecological monitoring of the seafloor (REMOTS ${ }^{\mathrm{TM}}$ system). Mar Ecol Prog Ser 8: $115-128$

Santos IR, Eyre BD, Huettel M (2012) The driving forces of porewater and groundwater flow in permeable coastal sediments: a review. Estuar Coast Shelf Sci 98:1-15

Silvert W, Sowles J (1996) Modelling environmental impacts of marine finfish aquaculture. J Appl Ichthyol 12:75-81

* Simone M, Grant J (2017) Visual assessment of redoxcline compared to electron potential in coastal marine sediments. Estuar Coast Shelf Sci 188:156-162

Soetaert K, Herman PM, Middelburg JJ (1996) A model of early diagenetic processes from the shelf to abyssal depths. Geochim Cosmochim Acta 60:1019-1040

* Solstorm F, Solstorm D, Oppedal F, Fernö A, Fraser TWK, Olsen RE (2015) Fast currents reduce production performance of post-smolt Atlantic salmon Salmo salar. Aquacult Environ Interact 7:125-134

Soto D, Aguilar-Manjarrez J, Hishamunda N (eds) (2011) Building an ecosystem approach to aquaculture. FAO/ 
Universitat de les Illes Balears Expert Workshop, 7-11 May 2007, Palma de Mallorca, Spain. FAO Fish Aquacult Proc 14, FAO, Rome

Stead SM, Laird L (2002) The handbook of salmon farming. Springer, London

Stigebrandt A, Aure J, Ervik A, Hansen PK (2004) Regulating the local environmental impact of intensive marine fish farming: III. A model for estimation of the holding capacity in the modelling-ongrowing fish farmmonitoring system. Aquaculture 234:239-261

Stucchi D, Sutherland TA, Levings C, Higgs D (2005) Nearfield depositional model for salmon aquaculture waste. In: Hargrave BT (ed) Environmental effects of marine finfish aquaculture. Springer, Berlin, p 157-179

Talin F, Tolla C, Rabouille C, Poggiale J (2003) Relations between bacterial biomass and carbon cycle in marine sediments: an early diagenetic model. Acta Biotheor 51: 295-315

Vezzulli L, Chelossi E, Riccardi G, Fabiano M (2002) Bacterial community structure and activity in fish farm sediments of the Ligurian Sea (Western Mediterranean).

Editorial responsibility: Catriona MacLeod,

Hobart, Tasmania, Australia
Aquacult Int 10:123-141

*Wang X, Olsen LM, Reitan KI, Olsen Y (2012) Discharge of nutrient wastes from salmon farms: environmental effects, and potential for integrated multi-trophic aquaculture. Aquacult Environ Interact 2:267-283

Wilding TA, Cromey CJ, Nickell TD, Hughes DJ (2012) Salmon farm impacts on muddy-sediment megabenthic assemblages on the west coast of Scotland. Aquacult Environ Interact 2:145-156

* Wildish D, Hargrave B, Pohle G (2001) Cost-effective monitoring of organic enrichment resulting from salmon mariculture. ICES J Mar Sci 58:469-476

Wildish D, Dowd M, Sutherland T, Levings C (2004) Nearfield organic enrichment from marine finfish aquaculture. Can Tech Rep Fish Aquat Sci 2450:3-10

*Wilson PS, Vopel K (2012) Estimating the in situ distribution of acid volatile sulfides from sediment profile images. Limnol Oceanogr Methods 10:1070-1077

Zirino A, Neira C, Maicu F, Levin LA (2013) Comments on and implications of a steady-state in coastal marine ecosystems. Chem Ecol 29:86-99

Submitted: October 12, 2017; Accepted: March 14, 2018

Proofs received from author(s): June 6, 2018 